\title{
Migranti in preobrazba sosesk: raziskava družbenogospodarske preobrazbe sydneyjskega predmestja Lidcombe
}

Eden od glavnih razlogov za negativen odnos do migrantov je dejstvo, da obremenijo objekte in infrastrukturo gostiteljske skupnosti, sami pa veliko ne prispevajo h gospodarstvu in družbi države gostiteljice. Ta negativni odnos je močen zlasti v mestih, kjer je pritisk na javne dobrine zgoščen in opaznejši. Zato so migrantske soseske še posebej zaničevane. $S$ tem stereotipnim pogledom se ne ujemajo izkušnje z migranti v okolici pokopališ̌ča Rookwood Cemetery v Sydneyju, ki velja za »največjo nekropolo na južni polobli«.V tej migrantski soseski potekajo živahne in raznovrstne dejavnosti (zlasti korejskih) migrantov, ki so za to območje, znano pod imenom Lidcombe, nekaj popolnoma novega. Na podlagi različnih virov, analiziranih z zgodovinsko-strukturnega vidika migracijskih študij, vključno $\mathrm{z}$ arhivskimi raziskavami v lokalnih knjižnicah, pogovori z dolgoletnimi prebivalci tega območja in vidno etnografijo, so v članku predstavljeni zgodovina Lidcomba in njegove izkušnje z migranti v 21. stoletju.
Pri tem avtorja na podlagi demografskih, družbenih in geografskih sprememb poudarjata prispevek migrantov $\mathrm{k}$ prenovi »mrtvega mesta « in izpodbijata podedovane stereotipe, ki pogosto vodijo $\mathrm{k}$ rasistični obravnavi migrantov kot »grešnih kozlov « ter na podlagi katerih se migranti prikazujejo kot » paraziti « in »kriminalci «, ki »izčrpavajo « gospodarstvo države gostiteljice. Predstavljena študija primera kaže, da lahko migranti prostore, v katerih živijo, pogosto preoblikujejo tako, da pozitivno in dolgotrajno prispevajo h gospodarstvu in družbi države gostiteljice. Ta primer bi morale kot pomembno lekcijo upoštevati tako evropske države, ki se soočajo $\mathrm{z} \gg$ migrantsko krizo «, kot tudi politiki po svetu, ki želijo gostiteljska gospodarstva in družbe pred migranti zaščititi z zidovi.

Ključne besede: mestno pokopališče, migracije, migranti, lokalni gospodarski razvoj 


\section{Uvod}

Kako migranti oblikujejo prostore, $\mathrm{v}$ katerih živijo, ter prispevajo h gospodarstvu in družbi države gostiteljice? Dolgoletne raziskave migracij po vsem svetu so pokazale, da kadar v družbi prevlada mnenje, da migranti obremenjujejo objekte in infrastrukturo gostiteljske skupnosti, so ti brezposelni in malo ali sploh ne prispevajo h gospodarstvu in družbi države gostiteljice. Ker to mnenje pogosto prevlada, se negativen odnos do migrantov močno okrepi in včasih doseže vrelišče (Markaki in Longhi, 2013). Trenutna »migrantska kriza « v Evropi, Severni in Južni Ameriki ter drugod po svetu dobro ponazarja to stališče in kaže, da so migranti med ljudmi običajno nezaželeni. Iz diskurza »usmiljenja «, ki ga uporabljajo redke države, ki sprejemajo ukrepe za to, da bi migrante lepo sprejele, je razvidno, da ljudje migrante dojemajo kot parazite oziroma izkoriščevalce družbenogospodarskih ugodnosti ter razdiralce varnosti in političnega miru. Tak negativni odnos je močen zlasti v mestih, kjer je pritisk na javne dobrine zgoščen in opaznejši. Zaradi tega se migrantske soseske po svetu pogosto opisujejo kot prostori, v katerih živijo kriminalci ter prevladujejo nezakonite in nepoštene dejavnosti, stanovanja slabe kakovosti, slabe bivalne razmere, kriminal, umazanija in nizka stopnja varnosti (glej Collins, 2008 in 2013, Tsenkova, 2014; Opoko idr., 2015). Tem predstavam nasprotujejo nekatere raziskave (na primer Stilwell, 2003, ter Obeng-Odoom, 2012a in 2014), ki kažejo, da so izkušnje migrantskih naselij kompleksnejše. Novejša priljubljena knjiga Douga Saundersa (2012) z naslovom Arrival City prikazuje, kako so lahko migranti uspešni v procesu migracije, vendar gre $\mathrm{v}$ tem primeru za poljudnoznanstveno delo, ki se metodološko bolj posveča posameznikom kot njihovim družbenim odnosom ali migrantskim soseskam na splošno (Davidson in Gleeson, 2013). Izsledki raziskav tradicionalne migracije $s$ podeželja v mesta (za pregled glej Acharyja in Codina, 2012), zlasti tistih s področja osrednje ekonomije, prav tako niso v veliko pomoč, saj običajno preučujejo migracije na podlagi dejanj posameznikov in gospodinjstev znotraj nacionalnih meja, pri čemer se več kot očitno ne zmenijo za transnacionalne in medcelinske migracije niti za to, da jih določajo strukturni ter institucionalni dejavniki in procesi (Adogame in Lawrence, 2013; Ozkul in Obeng-Odoom, 2013, ter Portes in Yiu, 2013). Sistematične raziskave transnacionalnih migracij so se veliko manj osredotočale na migrantske soseske, ki so tudi v literaturi zelo redko obravnavane, če pa so, se navezujejo na begunce in njihove enklave oziroma naselja (na primer Stilwell, 2003). Metem ko so nas migracijske študije veliko naučile o značilnostih migrantov kot delovni sili, se osredotočajo bolj na dinamiko posameznikov. V raziskavah migracij in gospodarstva se pridevnik »gospodarski « običajno nanaša samo na rast, produktivnost in trge dela. Poleg tega se veliko raziskav osredotoča na razmere v Veliki Britaniji in
ZDA (glej na primer Riley in Weale, 2006), zato bosta analiza vloge migrantov pri preobrazbi celotnih sosesk (drugačen pogled) in preusmeritev pozornosti na Avstralijo (drugačno visoko razvito kapitalistično državo) pomagala poglobiti naše razumevanje »gospodarnosti migracij«. Članek dopolnjuje in močno razširja obstoječa prizadevanja za boljše razumevanje migrantskih naselij ter tako osvetljuje vlogo migracij pri družbenogospodarski preobrazbi migrantskih prostorov ter gospodarstev in družb držav gostiteljic.

Empirični del raziskave se osredotoča na migrantsko sosesko Lidcombe v Sydneyju. Nahaja se »v občini Auburn na tradicionalnem ozemlju plemena Darug ter obdaja železniško postajo in majhen nakupovalni center. $\mathrm{Na}$ severu sega do ulice Parramatta Road, na vzhodu pa do pokopališča Rookwood Cemetery. $\mathrm{Na}$ zahodu in jugu se združi s predmestjema Auburn in Berala. Pokrajina je precej ravna in se večinoma spušča proti reki Parramatta « (Kass, 2008, brez navedbe strani). To je pomembno zaradi treh stvari. Prvič, raziskava se razlikuje od drugih raziskav v okviru avstralskih migracijskih študij, ki se večinoma osredotočajo na trgovine oziroma podjetja $\mathrm{v}$ lasti migrantov (na primer Collins idr., 2011), delavske razmere začasnih in stalnih migrantov (na primer Hugo, 2008, ter McGrath-Champ idr., 2011) ter pozitivne učinke denarnih nakazil migrantov v domovino (Obeng-Odoom, 2010), ne pa na njihov prispevek $\mathrm{k}$ preobrazbi avstralskih sosesk - razen nekaterih pomembnih izjem (glej na primer Stilwell, 2003). Drugič, gre za prvo znanstveno študijo Lidcomba kot migrantske soseske. V časopisu Sydney Journal so bile dokumentirane izkušnje drugih sydneyjskih predmestij, kot sta Berala (Gordon, 2008) in Croyden (Johnson, 2009), pri čemer pa migracije niso bile glavna tema, soseska Lidcombe, ki je v tem pogledu izjemno pomembna, pa je bila v celoti izpuščena. Še na slavno publikacijo Liberty Plains: A History of Auburn, $N S W$ so letele kritike, ker je bila soseska Lidcombe v izdajah iz let 1983 in 1986 izpuščena. Na podlagi teh kritik je bila nato leta 1992 pripravljena popravljena izdaja (glej Hedges, 1992), v kateri pa je bil izpuščen vidik migracii; kot v prejšnjih izdajah je bil glavni poudarek na zgodovini soseske. Tretjič, raziskava opozarja na procese, politiko in smernice, ki pogosto manjkajo v rastočem številu publikacij o mestih in migracijah, kot sta Triumph of the City (Glaeser, 2012) in Arrival City (Saunders, 2012), zaradi česar številni kritični urbanisti (glej na primer Davidson in Gleeson, 2013, in Obeng-Odoom, 2013) zahtevajo nadaljnje in širše raziskave pojava migracij v mestih. V publikaciji avstralske vlade z naslovom State of Australian Cities Report 2013 (Department of Infrastructure and Transport, 2013) avtorji obžalujejo slabo razumevanje dinamike migrantskih sosesk v Avstraliji, medtem ko Pau Serra (2012) v prispevku v tej publikaciji poudarja, da je v Severni Ameriki veliko migrantov, zelo malo pa je raziskav tega, kako migranti preoblikujejo urbane in regionalne prostore. 
Avtorja sta podatke za analizo pridobila na podlagi: 1 . več pogovorov z ljudmi, ki na obravnavanem območju živijo zadnjih 10-30 let, vključno z železniškimi delavci, zaposlenimi v knjižnici, lastniki trgovin, stanovalci in poštnimi delavci; 2. preučevanja arhivskega materiala v knjižnicah $\mathrm{v}$ Lidcombu in Auburnu, in sicer zlasti preteklih izdaj lokalnega časopisa Auburn Review; 3. poizvedb v nepremičninskih agencijah $\mathrm{v}$ Lidcombu in sosednjih predmestnih soseskah; 4. terenskih ogledov preučevanega območja $\mathrm{v}$ kombinaciji $\mathrm{z}$ vidno etnografijo $\mathrm{z}$ namenom fotografiranja informacij na spominskih ploščah na zgodovinskih stavbah; 5. cerkvenih pridig; 6. statističnih informacij v biltenih avstralskega statističnega urada in 7. različnih publikacij lokalnega sveta v Auburnu.

Analitični okvir raziskave temelji na zgodovinsko-strukturni paradigmi analize migracij. V nasprotju z neoklasično ekonomijo, ki poudarja posamezne racionalne dejavnike kot gonila migracij znotraj ahistorične pripovedi o maksimiranju dobička, poudarja zgodovinsko-strukturna paradigma migracijske procese kot del strukturnih sprememb v družbi. Ta pristop upošteva posamezne razloge za migracijo, vendar večinoma v dialektičnem odnosu s skupinskimi motivi za notranje ali zunanje selitve, in je usmerjen $\mathrm{v}$ induktivno sklepanje (Abreu, 2012). Različico tega pristopa je uspešno uporabil že Frank Stilwell (2003), ko je preučeval migracije afganistanskih beguncev ter njihove posledice za lokalni in regionalni gospodarski razvoj v sydneyjski soseski Young. Od takrat je bilo opravljenih še vsaj 19 podobnih raziskav, ki so bile enako uspešne in so temeljile na omenjenem delu ${ }^{[1]}$. Čeprav ta pristop ne omogoča oblikovanja jasnih modelov $s$ kvantitativnimi in kategoričnimi odgovori, zaradi česar je po mnenju nekaterih gospodarstvenikov, usmerjenih v ekonometrične analize, prešibek (glej na primer Molho, 2013), ima pomembne prednosti. Je preglednejši, lažje ga je postaviti pod drobnogled javnosti in je bolj realističen, saj upošteva raznolikost, negotovost in kompleksnost dejavnikov, ki so v restriktivnih modelih neoklasične ekonomije pogosto spregledani. Ti modeli namreč temeljijo na spornih domnevah homo economicusa, prizadevanju za razmere, ki bi bile najboljše za vse, in na popolnih informacijah (Stilwell, 2003). Vse to pa za obravnavano raziskavo ni uporabno.

Življenje v Lidcombu se močno razlikuje od tega stereotipnega pogleda. Soseska se razteza znotraj največjega pokopališča na južni polobli, čezenj ali prek njega. V skladu z evidenco pokopališča in nagrobnimi napisi, zabeleženimi med novejšimi prečnimi terenskimi ogledi območja, je tam pokopanih več kot 800.000 ljudi. V 21. stoletju so migracije to sosesko, ki je bila prej znana predvsem kot pokopališče za lokalne prebivalce, spremenile $\mathrm{v}$ živahno in razvejano lokalno gospodarstvo z nizko stopnjo kriminala in umazanije. Je primer pozitivne družbenogospodarske preobrazbe, ki so jo sprožili migranti. Lidcombe je danes znan kot »prizorišče olimpijskih iger leta 2000 «, »sedež korejskih cerkva « in »kraj, na katerem se počutiš kot doma «. Pokopališče in velik pogrebni zavod sta še vedno tam, vendar nista več temelj lokalnega gospodarstva, ki je trenutno izjemno razvejano in vključuje najrazličnejše dejavnosti, kot so gostinstvo, trgovina, frizerstvo, farmacija, poslovanje $\mathrm{z}$ nepremičninami in razvedrilne dejavnosti. $\mathrm{V}$ nasprotju z letom 1904, ko je v Lidcombu živelo 4.500 belopoltih Avstralcev in Britancev (Hedges, 1992), danes tam živi več kot 15.000 ljudi iz več kot 30 držav, lokalno gospodarstvo pa temelji na migrantskih podjetjih. Pri tej uspešni preobrazbi ni šlo za preprost primer vzroka in posledice. Migranti so prispevali $\mathrm{k}$ preobrazbi, vendar so jih $\mathrm{k}$ temu pritegnili drugi dejavniki. Kljub vsemu je preobrazba hkrati Ahilova peta soseske: cene nepremičnin so se močno povečale in tako Lidcombe ni več cenovno ugodna soseska, ki je pred desetletjem sprejemala migrante in jim pomagala uresničiti »avstralske sanje «.

Članek je razdeljen na tri dele. V prvem delu je predstavljena družbenogospodarska zgodovina Lidcomba, pri čemer je glavni poudarek na obdobju pred prihodom migrantov. $V$ drugem delu avtorja preucuujeta razmere od » migracijske dobe « naprej, pri čemer se osredotočata na značilnosti, dejavnosti in prispevek migrantov, $\mathrm{v}$ zadnjem delu pa razmišljata o posledicah preobrazbe za migrante, ki na tem območju živijo, in druge potencialne migrante.

\section{Lidcombe: zgodnje obdobje}

Družbeno zgodovino Lidcomba lahko razdelimo na tri teme oziroma obdobja: obdobje nepomembnosti, obdobje gospodarskega razcveta in obdobje gospodarskih težav. Vsako posebej je obravnavano v nadaljevanju.

\subsection{Temelji soseske in obdobje nepomembnosti}

Lidcombe leži v zahodnem delu Sydneyja. Prvotno naselje se je razvilo na zemljišču ob potoku, ki je bil leta 1804 last Samuela Haslama. Območje je dobilo ime Haslam's Creek (slo. Haslamov potok), na njem pa so živeli večinoma ljudje, ki so se tja priselili iz Velike Britanije. Potok so uporabljali pri gospodinjskih opravilih in se sproščali na njegovih bregovih (Hedges, 1992). Med začetkom 20. let in začetkom 30. let 19. stoletja so bili lastniki zemljišč na tem območju še sir Thomas Brisbane, George Tuckwell in George Sunderland. Po navedbah Johna Mitchella (2008) pa je bil oče John Joseph Therry tisti, čigar dejavnosti so najbolj spremenile potek razvoja tega območja. Po rodu je bil Irec in eden od dveh katoliških duhovnikov, ki so ju v kolonialnem obdobju poslali v Novi Južni Wales opravljat pastoralno delo, hkrati je bil eden od prvih posameznikov, ki so kupili parcele na območju, danes znanem kot Lidcombe. Zemljišča je kupil kot naložbo in ne toliko zaradi 
osebnega dobička; želel je razširiti svoje pastoralno delo, še zlasti zato, ker je padel v nemilost pri cerkvi in ni več prejemal letne plače $\mathrm{v}$ višini $100 \mathrm{GBP}$. Njegova poslovna strategija je bila zelo preprosta: kupuj po čim nižji ceni in prodajaj po čim višji. Tako je leta 1831 cerkvi za 60 akrov veliko parcelo plačal 15 GBP, leta 1843 pa je od Sunderlanda kupil 160 akrov zemlje za 40 GBP.

Izjemna priložnost se mu je pokazala leta 1855 , ko so mu odvetniki sydneyjskih železnic predlagali, da bi od njega kupili 10 akrov zemljišč za izgradnjo železniške proge med Parramatto in Sydneyjem. Oče Therry je ponudbo sprejel in za zemljišča prejel $100 \mathrm{GBP}$, kar je bila dobra kupčija glede na to, koliko je sam plačal zanje. Drugi lastniki zemljišč na tem območju so ugotovili, da bi izgradnja železniške postaje v Haslam's Creeku oživila lokalno gospodarstvo in povečala vrednost nepremičnin, zato so očeta Therryja prepričali, naj še dodatno podpre naložbe v to območje. Oče Therry se je s tem strinjal, in zamisel so potrdili tudi pri sydneyjskih železnicah. Edini problem je bil $\mathrm{v}$ tem, da so morali predlagatelji plačati stroške izgradnje železniške postaje, ki so znašali 700 GBP. Therry je prispeval 100 GBP, ki jih je prejel od prodaje svoje zemlje, preostala sredstva pa so prispevali drugi (Mitchell, 2008). Oče Therry tako ni bil samo nekdo, ki je svojo zemljo prodal, da bi omogočil razvoj železniškega prometa $\mathrm{v}$ Lidcombu, ampak je vlagal tudi v razvoj območja. Postaja v Haslam's Creeku je bila odprta leta 1859 (Pollen, 1988).

Kmalu je začelo na tem območju nastajati predmestje. Po navedbah Stanleyja L. Hedgesa (1992) »je izgradnja železniške proge močno spremenila status okrožja «. Zgrajene so bile ceste, $s$ katerimi je to območje postalo neodvisno; prva je bila leta 1862 zgrajena ulica John Street na severu Lidcomba, ki so jo poimenovali po očetu Therryju. Poleg tega je bila zgrajena še ena cesta in stanovanjska soseska »Town of St. Joseph «, ki je naznanila širitev naselja (Hedges, 1992). Železniška postaja je bila glavno gonilo (urbanega) razvoja Lidcomba.

Leta 1862 je vlada Novega Južnega Walesa kupila 200 akrov zemlje za izgradnjo »največjega pokopališča na južni polobli« (Emerson, 2001: 24). Pokopališče je bilo dokončano leta 1867 in poimenovali so ga Haslam's Creek Cemetery. Domačini so močno protestirali proti temu, da bi se ime njihovega naselja povezovalo s pokopališčem. Stigmatizacija je bila več kot očitna, kar dokazujejo tudi ti komentarji: »vse, kar moraš narediti, je, da ,greš tja in padeš notri ...' «; » večina ljudi pravi, ,če ne prej, boš to sosesko obiskal, ko boš umrl'«; »naselje vodijo ljudje, ki izdelujejo nagrobnike, in grobarji (opazke o Lidcombu iz leta 1904, navedeno v Hedges, 1992: 232 in 233).

Vse to je vplivalo tudi na to, kako so oglaševali zemljo na tem območju. Pogosto so na prodaj ponujali zemljo v »Town of
St. Joseph ob železniški postaji Haslam’s Creek« (Hedges, 1992: 224) - brez omenjanja pokopališča. Oblasti so se na proteste odzvale tako, da so leta 1878 naselje preimenovale $\mathrm{v}$ Rookwood po tem, ko so se odločale med več imeni. Nekateri pravijo, da je na njihovo končno izbiro vplival naslov knjige Williama Harrisona, objavljene okrog leta 1838 (Pollen, 1988, in Emerson, 2001), po poročanju enega od časopisov pa so to ime izbrali zato, ker je na tem območju živelo veliko poljskih vran (ang. rooks) ${ }^{[2]}$, zaradi česar naj bi bilo primernejše kot imeni Fitzroy in Norwood, ki sta bili prav tako predlagani (Hedges, 1992).

Občina Rookwood je bila ustanovljena čez več let (leta 1891). Sedem let po ustanovitvi so se začeli prebivalci spet pritoževati nad isto stvarjo: s povezovanjem pokopališča Rookwood Cemetery s sosesko Rookwood. Na tem območju pa so bili še drugi objekti, ki so vzbujali negativne asociacije. Leta 1879 so na primer v Lidcombu kupili 1.340 akrov zemlje za izgradnjo popravnega doma za mladoletne prestopnike. Ta je bil leta 1893 preurejen v azil za revne, starejše in slabotne, katerih življenjske razmere so povzročile ali poslabšale vse večje gospodarske težave (to piše na plošči, ki jo je dal izdelati urad za obeleženje dvestoletnice Avstralije in je nameščena na vhodu današnje vratarnice). Očitno pa je največ preglavic še vedno povzročalo ime območja. Leta 1914 je bilo zato naselje spet preimenovano, tokrat $\mathrm{v}$ Lidcombe. To ime je bilo izpeljano iz priimkov dveh nekdanjih županov (Lidbury in Larcombe; Pollen, 1988, in Emerson, 2001) in se je obdržalo do danes.

Svetovna gospodarska kriza v 30. letih 20. stoletja je naselje močno prizadela. $\mathrm{V}$ rubriki »Leta svetovne gospodarske krize « je mestni svetnik Stanley L. Hedges (1992) navedel, da so se takrat $\mathrm{v}$ gospodarstvu Lidcomba ponovile razmere iz 90. Let 19. stoletja. Večini revnih ljudi v Lidcombu v drugi polovici 20. let preǰ̌njega stoletja je bil pojem gospodarske krize najverjetneje čuden, saj so bili prej vedno odvisni od državne podpore (nadomestil za brezposelne ter tudi od nedenarne pomoči, kot so bili odeje in vojaška oblačila) in pomoči dobrodelnega društva v Lidcombu. Gospodarska kriza je kljub temu prinesla velike izzive. Občinski svet je začel uvajati obsežne varčevalne ukrepe in zmanjšal plače osebju, ki je še ostalo. To je še bolj obremenilo lokalno gospodarstvo, ki mu že tako ni kazalo dobro. Terry Kass (2008) navaja, da je bilo med gospodarsko krizo brez dela približno $23 \%$ prebivalcev Lidcomba, kar je občinski svet prisililo $k$ temu, da je sprejel vladni program, v okviru katerega so ljudje prejeli državno podporo kot plačilo za opravljeno delo. Kljub temu je bilo še vedno veliko ljudi brezposelnih - med letoma 1931 in 1932 so morali urediti celo » taborišče za brezposelne «. Zaposlitvene možnosti so bile tako slabe, da je moral občinski svet $\mathrm{v}$ določenem trenutku z »žrebanjem « določiti, kdo bo dobil tistih nekaj služb, ki so bile na voljo. Število brezposelnih je bilo že tako 
veliko, da so lahko ustanovili sindikat brezposelnih delavcev v Lidcombu (Hedges, 1992), poleg tega so bile organizirane tudi ljudske kuhinje za otroke in brezposelne (Kass, 2008).

\subsection{Obdobje gospodarskega razcveta}

Štirideseta leta 20. stoletja so bila za Lidcombe zlata doba. Po besedah dolgoletnega prebivalca je bil Lidcombe »živahno in podjetno predmestje, ki je imelo svoj mestni svet in tesno povezano skupnost « (Auburn Review, 1988, brez navedbe strani). Ustanovljena je bila gradbena zadruga, ki naj bi spodbudila izvajanje obsežnega programa stanovanjske gradnje in tako številnim prebivalcem omogočila, da pridejo do svoje hiše (Hedges, 1992). Lidcombe je cvetel, saj je bilo lokalno gospodarstvo $\mathrm{v}$ razmahu, in njegovi prebivalci so bili zaposleni v naselju ali zunaj njega. Tam so bile pekarne in mlekarne, dostavne službe in tovarna letalskih motorjev. Mestni svet je sprejel ambiciozen program za dvig kakovosti in števila stanovanj, ki je dopolnjeval »obsežni program za izboljšanje ulic v Lidcombu z urejanjem pločnikov, odtočnih kanalov in asfaltiranjem cest «, ki so ga začeli izvajati leta 1929 in je trajal vse do leta 1937 (Hedges, 1992: 285) oziroma še dalj. Po navedbah domačinov je v nekem trenutku v naselju delovalo šest bank. Trgovine s sadjem, čevlji in žensko modo so cvetele, prav tako trgovine $\mathrm{z}$ živili. $\mathrm{V}$ določenem trenutku je bilo $\mathrm{v}$ Lidcombu kar pet pekarn. Prebivalci so delali pri železnici, $\mathrm{v}$ bolnišnici, na pokopališču in $\mathrm{v}$ veliki klavnici, ki je stala na območju sedanjega olimpijskega parka (glej sliko 1). Državna klavnica je zaposlovala 1.600 ljudi, od teh jih je veliko prihajalo iz Lidcomba (Hedges, 1992). Drugi so delali v večjih tovarnah in poslovnih enotah v Lidcombu ali njegovi okolici. Šlo je za tovarne Ford, Australian Forge, Dahaviland, Janson's, Bradford Insulation in Australian Electrical Industries. Drugi so delali v podjetjih Dairy Farmers, Barbcock \& Wilcox, Egg Board, Tooyer's Brewery in Coats Printing. Lokalna skupnost je bila majhna, ampak zelo povezana in tovariška, zaradi česar je bila stopnja kriminala zelo nizka.

Gospodarsko rast Lidcomba so spremljala prizadevanja za ohranjanje povezanosti skupnosti. $\mathrm{V}$ ta namen so ustanovili plesne klube in organizirali športne dejavnosti. Doma in v službi so dosledno učili »spoštovanje, odgovornost in disciplino «, čemur so sledili tako mladi in stari. To sta poudarila dolgoletna prebivalca Lidcomba. Leta 1949 je mestna uprava zaradi učinkovitejšega upravljanja Lidcombe združila z Auburnom v občino Auburn (Emerson, 2001). Odločitev je bila sporna, saj so nekateri prebivalci in celo mestni svetniki menili, da združitev ne bi bila pametna, med drugim tudi zato, ker bi moral Lidcombe prevzeti dolgove, ki si jih ni sam nakopal (Hedges, 1992). Kljub temu je do združitve prišlo in vsaj takrat se je zdelo, da ta ni ovirala razvoja - ne doma ne v službi ne na ravni mestne uprave.
Lidcombovo obdobje gospodarskega razcveta je bilo organsko povezano z razmahom, ki ga je takrat doživljalo vse avstralsko gospodarstvo. Ta povojni razmah med letoma 1945 in 1975 ni bil povezan z gospodarsko arhitekturo britanskega imperija, čeprav je Velika Britanija kot kolonialna gospodarica ustanovila avstralsko kolonijo ter ji od leta 1788 do 90 . let 19. stoletja pošiljala delovno silo in kapital. Med letoma 1946 in 1948 ter 1966 in 1968 se je izvoz v Veliko Britanijo zmanjšal za $65 \%$, uvoz iz Velike Britanije pa za 56 \% (Broomhill, 2008). Avstralija se je na področju trgovine in tudi kulturne izmenjave vse bolj obračala $\mathrm{k}$ novi svetovni velesili - ZDA - in svoji sosedi - Aziji. Vse več tujih podjetij je odpiralo svoje podružnice v Avstraliji in tako sodelovalo v gospodarskem razcvetu oziroma prispevalo $\mathrm{k}$ njemu (Broomhill, 2008). V skladu $s$ prevladujočo miselnostjo tistega časa je avstralska vlada podprla keynesianstvo ter $\mathrm{z}$ uporabo javnih sredstev zagotovila subvencije za stanovanja, zdravstvo, izobraževanje in prehrano (Broomhill, 2008). Gospodarski razcvet je ustvaril potrebo po migrantski delovni sili. Tako je avstralska vlada po letu 1947 začela uvajati aktivno politiko privabljanja migrantov. Priseljenci so takrat predstavljali približno polovico rasti avstralskega prebivalstva. Med migranti, ki so se odzvali na to politično pobudo, so prevladovali Evropejci, zlasti Britanci, in prebivalci Oceanije (zlasti Novozelandci; Collins, 2008). Konec tega razcveta in začetek drugega cikla gospodarskega upada v Avstraliji - to obdobje je politični gospodarstvenik, ki je bil dobro seznanjen $s$ takratnimi razmerami, poimenoval $\gg$ kriza 70. in 80. let 20. stoletja « (Broomhill, 2008: 21) - so občutili tudi v Lidcombu.

\section{3 "Postavimo Lidcombe spet na noge»}

Leta 1988 je bil v časopisu Auburn Review objavljen članek $\mathrm{z}$ naslovom Postavimo Lidcombe spet na noge!, v katerem je zajeto splošno vzdušje tistega časa. Šlo je za intervju s Keithom Huteaujem, uradnikom za stike z mediji pri združenju za izboljšanje skupnosti v Lidcombu in nekdanjim mestnim svetnikom. Huteau je spregovoril o smrti gospodarske zbornice v Lidcombu in o svoji želji, da bi jo oživili. Njegova ocena težav je še zgovornejša: »Rekel je, da je Lidcombu začel zvoniti mrtvaški zvon z izgradnjo nove hitre ceste, ki naj bi po njegovem mnenju preusmerila glavni tok kupcev proč od nakupovalnega središča v Lidcombu.« Dolgoletna prebivalca Lidcomba, $s$ katerima smo se pogovarjali o Huteaujevi oceni, sta se z njim strinjala, zadevo pa sta še dodatno pojasnila. Zaradi hitre ceste so bili porušeni lokali, trgovine in nekatere hiše, zaradi česar soseska ni izgubila samo posla, ampak tudi občutek družabnih »dobrih starih dni

Prebivalci so navedli še druge vzroke za gospodarsko nazadovanje. Po mnenju nekaterih je Lidcombe s tem, ko je izgubil status upravnega središča, izgubil tudi nekaj svojega sijaja, vse- 
kakor pa so se s tem končale dejavnosti v mestni hiši. Ker pa se je to zgodilo že leta 1949, je trajalo kar nekaj časa, preden so se posledice dejansko občutile. Na nacionalni in svetovni ravni so podjetja, ki so do takrat zaposlovala prebivalce Lidcomba, zapirala svoje tovarne ali jih selila drugam, da bi zmanjšala stroške ter se ob tem izognila zahtevam delavskih sindikatov za boljše in višje plače. Po svetu so se zaradi povečanja cen nafte in napredka v proizvodni tehnologiji povečali proizvodni stroški, hkrati pa se je zmanjšal uvoz iz Avstralije, ki je vključeval precejšnje količine kmetijskih proizvodov ali surovin (Stilwell, 1998, in Boomhill, 2008). Med prej omenjenimi podjetji sta se do danes obdržali samo Tooyer's Brewery in Coats Printing. Druga podjetja imajo v Lidcombu še vedno svoje podružnice, vendar so mirujoča ali pa že opuščena. To velja tudi za bazo avstralskih kraljevih zračnih sil. Ne glede na pravi vzrok so družbenogospodarske dejavnosti v Lidcombu do leta 1988 močno upadle, in ta trend se je nadaljeval do konca 90. let. Banke so zapustile območje in z njimi so odšla tudi delovna mesta. Ceste so bile v slabem stanju in vladne posege je začela nadomeščati nevidna roka trga. Javne stavbe v bližini ulice George's Avenue so prodali, kar se je skladalo s stališčem, da je »vitko« upravljanje najboljše, kar so avstralski gospodarstveniki imenovali tudi paradigma »ekonomskega racionalizma (Stilwell, 1979, 1998).

V primerjavi z drugimi obdobji se takrat v Avstralijo ni priseljevalo veliko ljudi (Collins, 2008). Politično zanimanje za globalizacijo je vodilo v nasprotujoče si rezultate, še zlasti zato, ker se je bogastvo kopičilo v rokah peščice, večini ljudi pa se je položaj poslabšal. Predmestja, še zlasti tista v zahodnem delu Sydneyja (vključno z Lidcombom), niso uspevala, in zdelo se je, da nosijo glavno breme globalizacije, ki je v sodobni Avstraliji postajala vse pomembnejša. Hkrati so podjetja podpirala »uvoz « migrantskih delavcev, ki naj bi zapolnili primanjkljaj delovne sile (Stilwell, 1998). Na prelomu tisočletja (to je leta 2000) pa so se ljudje spet začeli množično priseljevati v Avstralijo (Collins, 2008), po navedbah domačinov tudi v Lidcombe. Lokalni dejavniki, zlasti olimpijske igre, so bili močen magnet, toda na priseljevanje so vplivali tudi drugi dejavniki - azijska kriza med letoma 1997 in 1999 je na primer povzročila močno priseljevanje iz Azije (Castles, 2008). Ne glede na vse pa je bilo za življenje v Lidcombu prelomno leto 2000.

\section{Priseljevanje v »mrtvo mesto«: Lidcombe po letu 2000}

Olimpijske igre leta 2000 so spremenile podobo Sydneyja in njegovega predmestja. Eden od raziskovalcev je vzdušje po razglasitvi, da bodo olimpijske igre leta 2000 potekale v Sydneyju, opisal z besedo »zmagoslavno « (Handmer, 1995: 355). Olimpijske igre so pospešile razvoj vse občine Auburn in za

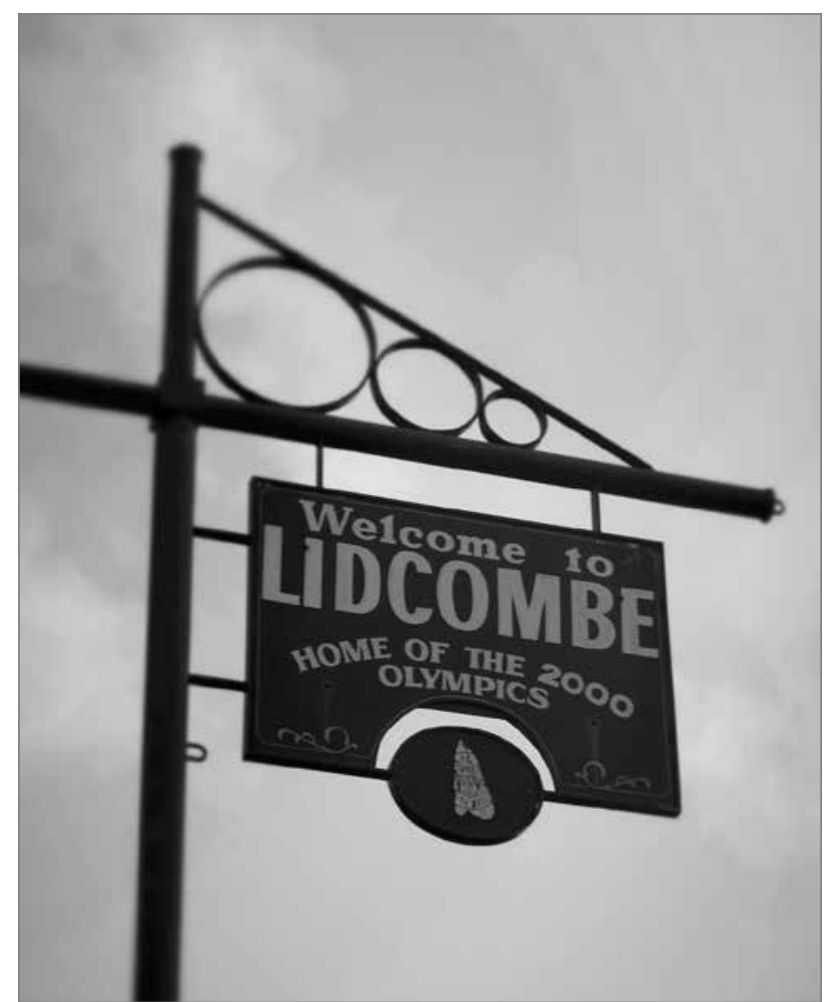

Slika 1: Lidcombe in olimpijske igre leta 2000 (foto: Hae Seong Jang)
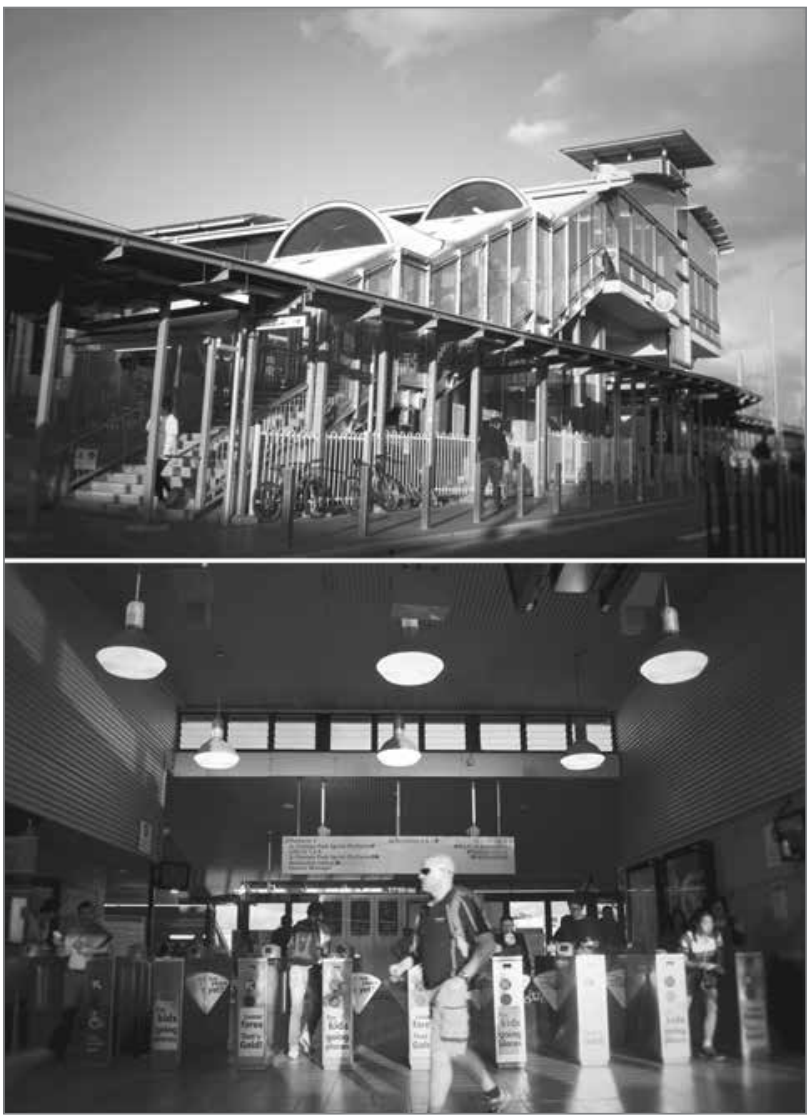

Slika 2: Sodobni železniški sistem v Lidcombu (foto: Hae Seong Jang) 


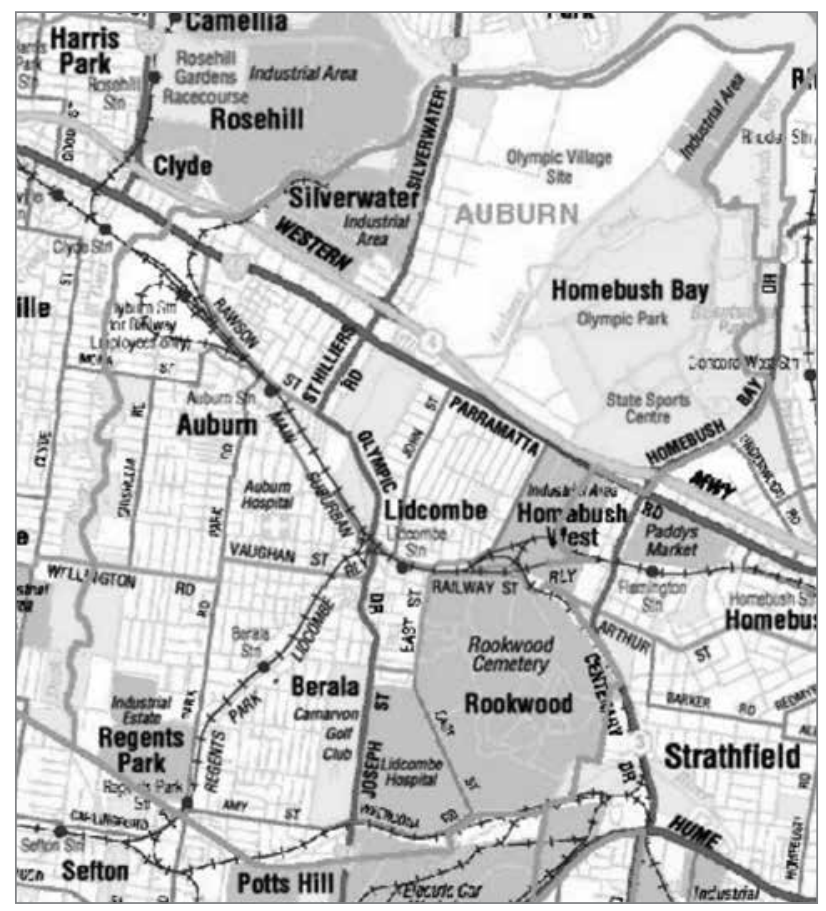

Slika 3: Zemljevid Lidcomba (vir: Division of Local Government, Department of Premier and Cabinet, 2013)

seboj pustile urbanistične projekte, ki so mestnim oblastem ustvarjali dohodke. Od štirih današnjih hotelov v Lidcombu sta bila vsaj dva zgrajena v fazi priprav na olimpijado, ki je tako postala zaščitni znak naselja (glej sliko 1).

Zgrajeni so bili nove hiše, olimpijski peron, dvigala in hitra cesta (Olympic Drive), ki naj bi privlačili obiskovalce in vsaj nekatere med njimi spodbudili $k$ temu, da bi se preselili na to območje. Prodaja vstopnic se je povečala, obiskovalci so najemali stanovanja v Lidcombu, ter kar je najpomembnejše, soseska je bila deležna precejšnje pozornosti na lokalni in državni ravni. Odprta je bila olimpijska železniška proga in promet v Lidcombu se je povečal. Lidcombe je postal pomembno železniško vozlišče ter postopoma so ga začeli svetu in drugim migrantom v Sydneyju, ki prej niso živeli v Lidcombu, prikazovati kot cretočo sosesko, ki je dobro povezana z drugimi predeli mesta. Sodobni železniški sistem (glej sliko 2) ostaja pomemben vidik življenja v soseski tudi po letu 2000.

Pred letom 2000 je v Lidcombu seveda živelo le malo nebritanskih priseljencev. Prvi priseljenci na tem območju, ki niso govorili angleško, so bili Rusi, Hrvati, Ukrajinci in Poljaki (Ashton, 2008). Med prvimi, ki so prišli v to sosesko, so bili tudi Italijani, ki so ob prihodu odprli tovarno mesnih izdelkov na ulici Joseph Street. V soseski je živelo dovolj Ukrajincev, da so lahko leta 1958 na ulici Church Street ustanovili veliko ukrajinsko cerkev, poleg tega so na isti ulici ustanovili še mladinski dom in srednjo šolo na ulici Joseph Street. Prvi večji val priseljencev je v Sydney najbrž prišel v 60. letih 20. stoletja po dolgem obdobju razcveta avstralskega gospodarstva po drugi svetovni vojni (Ashton, 2008). Migranti so torej Lidcombe odkrili že pred letom 2000. Migrantski val v 21. stoletju je bil z vidika števila in raznovrstnosti priseljencev pravzaprav nekoliko poseben. Trenutno migranti (to je ljudje, ki so se rodili na območjih, kjer angleščina ni prvi jezik) predstavljajo $59 \%$ prebivalstva v Lidcombu (Auburn City Council, 2013b), ki je del večje občine Auburn. Ta je sestavljena iz več predmestij, med katerimi so najpomembnejša Auburn, Berala, Homebush Bay, Regents Park in Silverwater (Auburn City Council, 2013b).

Večina trenutnih prebivalcev Lidcomba je priseljena iz neangleško govorečih držav. Čeprav velik delež migrantov predstavljajo Azijci, migranti na splošno prihajajo iz več kot 30 držav po svetu (preglednica 1). Struktura migrantov se torej razlikuje od značilne strukture migrantov v Avstraliji, pri kateri prevladujejo priseljenci iz Velike Britanije in Nove Zelandije (Collins, 2013).

Kot je razvidno iz preglednice 1 , se je struktura prebivalstva v Lidcombu z leti precej spremenila. Zlasti je očiten upad števila prebivalcev iz Libanona, Turčije, Hrvaške in Velike Britanije, kar zahteva nekoliko podrobnejšo analizo. Po navedbah domačinov naj bi bilo Libanoncev v preteklosti več kot zdaj, vendar so jih iz Lidcomba izrinili kitajski migranti, ki v Sydneyju in Avstraliji živijo že veliko dalj časa kot drugi priseljenci ter so v Lidcombu začeli kupovati zemljišča in stanovanja kot naložbe (po navedbah nepremičninskih agentov). Kitajci so rušili propadajoče stavbe, na njihovem mestu gradili nove in jih prodajali z dobičkom. $S$ tem so cene nepremičnin začele rasti hitreje, kot so si to lahko privoščili prebivalci Lidcomba, toda še vedno počasneje kot $\mathrm{v}$ drugih predelih Sydneyja, na primer v Auburnu. Proces se je začel sredi oziroma konec 90. let 20. stoletja z najavo, načrti in izvedbo obsežnega gradbenega projekta, povezanega s sydneyjsko olimpijado leta 2000 (Randolph idr., 2005).

V Urbanem izzivu je bilo objavljenih že veliko člankov o gentrifikaciji (na primer Kotze, 2013; Gunter, 2014; Monare idr., 2014, Marais idr., 2014, in Tsenkova, 2014), izkušnja v Lidcombu pa zahteva prav posebno pozornost. Proces tamkajšnje gentrifikacije je zelo podoben preobrazbi urbanih in predmestnih naselij v Sydneyju v smislu, da je z območij v bližini olimpijskega prizorišč izrinil revnejše ljudi in nanje pritegnil bogatejše (Stilwell, 1998). Hkrati gre za nekoliko poseben primer v smislu, da so denar in migranti skupaj ustvarili posebno urbano obliko, in sicer tako, da so z območja izrinili prejšnje prebivalce in poselili nekoč redko poseljeno predmestje.

$S$ procesom migrantske gentrifikacije pa ne moremo pojasniti nenavadnega primera libanonskih in turških migrantov. Raziskave (Burnley, 2006, in Mourad, 2009) kažejo, da je izgradnja 
mošeje Auburn-Gallipoli leta 1999 turške migrante (vključno z nekaterimi, ki so živeli v Lidcombu) spodbudila $k$ temu, da so se preselili v Auburn. Velik del finančnih sredstev za izgradnjo tega velikega verskega zbirališča za muslimane iz Libanona, Turčije ali od drugod je prispevala turška vlada ob podpori lokalnih muslimanskih priseljencev. Nekatere turške in libanonske priseljence v Lidcombu je spodbudila $\mathrm{k}$ temu, da so se preselili v Auburn - ne samo zato, ker so nekateri od njih lahko dobili stanovanje v stavbah v lasti uprave mošeje, ampak tudi zato, ker v Auburnu živi več libanonskih in turških muslimanov, ki ustvarjajo občutek »drugega doma « ter so močen magnet za muslimanske migrante iz Turčije, Libanona in od drugod, ki se v tej soseski zbirajo v vse večjem številu.

»Verski dejavnik « pa ne more pojasniti upada hrvaškega prebivalstva v Lidcombu med letoma 2001 in 2008. Kot kažeta raziskavi Val Čolić-Peisker (2004) in Walterja Lalicha (2004), objavljeni v reviji Croatian Studies Review, ter navedbe domačinov in analiza v knjigi Ilije Šutala z naslovom Croatians in Australia: Pioneers, settlers and their descendants (2004), je pravi vzrok za to najverjetneje spreminjajoča se narava hrvaških migrantov. V nasprotju z zgodnjimi hrvaškimi migranti, med katerimi so prevladovali delavci, ki so se v predmestjih in tamkajšnjih poceni hišah z vrtovi počutili udobno, zato so tam ostajali dalj časa, so mlajše in novejše skupine migrantov, ki bolje govorijo angleško, so bolj izobražene in imajo $s$ tem večje možnosti za izboljšanje svojih prihodkov, v predmestjih ostajale samo kratek čas in se nato preselile na boljše lokacije. Migranti iz delavskega razreda so se še naprej priseljevali v Avstralijo, toda Lidcombe zanje ni bil več privlačen, saj se vse večje število tamkajšnjih stanovanjskih zgradb Hrvatom ni zdelo najprimernejše za družinsko življenje. Poleg tega so Hrvati v Sydneyju veliko vlagali v skupnostne objekte zunaj Lidcomba (verske, izobraževalne ustanove, objekte za razvedrilne dejavnosti), zaradi česar je ta zanje postal manj privlačen.

Z nekoliko spremenjeno različico hipoteze »izrinjanja « lahko pojasnimo občuten upad deleža priseljencev iz Velike Britanije, ki živijo v Lidcombu. Od tam se je izselilo veliko belopoltih Avstralcev, vendar ne samo zato, ker so jih izrinili bogatejši priseljenci. Nekateri belopolti prebivalci so se namreč odselili zato, ker se niso želeli mešati s prihajajočimi skupinami migrantov. Po nekaterih drugih navedbah trgovine belopoltih Avstralcev $s$ prihodom migrantov niso več uspevale, ker so ti raje nakupovali v trgovinah v lasti migrantov, zato so se avstralski lastniki trgovin preselili. Prepričanje, da je Lidcombe naselje za migrante, bi bilo lahko še dodaten razlog za odvračanje belopoltega prebivalstva. Tudi postopno zmanjšsevanje števila belega prebivalstva je gotovo eden od razlogov, saj so dolgoletni prebivalci umrli, njihovi otroci pa so se odselili. Posledično pomanjkanje zanimanja za predmestje, $\mathrm{v}$ katerem so prevladovali migranti in ki je bilo znano kot soseska zanje, je še eden od razlogov. Poleg
Preglednica 1: Demografska struktura Lidcomba v obdobju 20012011 (v deležih)

\begin{tabular}{|c|c|c|c|}
\hline Država rojstva & 2001 & 2006 & 2011 \\
\hline Kitajska & 9,5 & 10,5 & 11,3 \\
\hline Južna Koreja & 3,2 & 3,5 & 10,5 \\
\hline Vietnam & 7,9 & 6,9 & 6,2 \\
\hline Indija & 2,2 & 2,0 & 3,0 \\
\hline Filipini & 2,9 & 2,8 & 2,9 \\
\hline Šrilanka & 2,9 & 3,3 & 2,7 \\
\hline Libanon & 4,6 & 4,0 & 2,7 \\
\hline Turčija & 2,7 & 2,5 & 1,9 \\
\hline Nepal & 0,1 & 0,6 & 1,7 \\
\hline Hongkong & 1,3 & 1,3 & 1,6 \\
\hline Nova Zelandija & 1,6 & 1,5 & 1,2 \\
\hline Malezija & 0,7 & 0,7 & 1,1 \\
\hline Burma & 1,4 & 0,9 & 1,1 \\
\hline Pakistan & 0,5 & 0,6 & 0,9 \\
\hline Indonezija & 0,4 & 0,5 & 0,9 \\
\hline Afganistan & 0,2 & 0,6 & 0,8 \\
\hline Bangladeš & 0,2 & 0,4 & 0,6 \\
\hline Hrvaška & 1,2 & 0,7 & 0,6 \\
\hline Velika Britanija & 1,1 & 0,7 & 0,6 \\
\hline Fidži & 0,9 & 0,6 & 0,6 \\
\hline Kambodža & 0,4 & 0,4 & 0,5 \\
\hline Irak & 0,6 & 0,9 & 0,5 \\
\hline Tonga & 1,1 & 0,9 & 0,4 \\
\hline Singapur & 0,1 & 0,4 & 0,4 \\
\hline Tajvan & 0,4 & 0,2 & 0,4 \\
\hline Tajska & 0,3 & 0,3 & 0,4 \\
\hline Južnoafriška republika & 0,1 & 0,2 & 0,3 \\
\hline Egipt & 0,2 & 0,3 & 0,3 \\
\hline ZDA & 0,1 & 0,1 & 0,3 \\
\hline Iran & 0,3 & 0,3 & 0,3 \\
\hline Italija & 1,0 & 0,6 & 0,3 \\
\hline Irska & 0,3 & 0,2 & 0,3 \\
\hline
\end{tabular}

Vir: Auburn City Council (2015a)

tega je treba upoštevati, da je Lidcombe vedno nosil stigmo »mesta mrtvih «, zato med belopoltimi Avstralci nikoli ni bil priljubljena lokacija. Kot je bilo že omenjeno, je večina angleških priseljencev, ki so se tja priselili v času nastajanja naselja, delala na pokopalǐ̌ču (Hedges, 1992), pri železnici (Mitchell, 2008), v klavnicah ali tovarnah v Lidcombu ali njegovi okolici. Nekateri belopolti prebivalci so se odselili tudi zato, ker so svoje nepremičnine ugodno prodali migrantom, drugi so svojim otrokom želeli zagotoviti boljše šolanje ali so odšli po tem, ko so njihovi otroci dokončali šolanje $\mathrm{v}$ tej soseski, nekaj pa jih je 


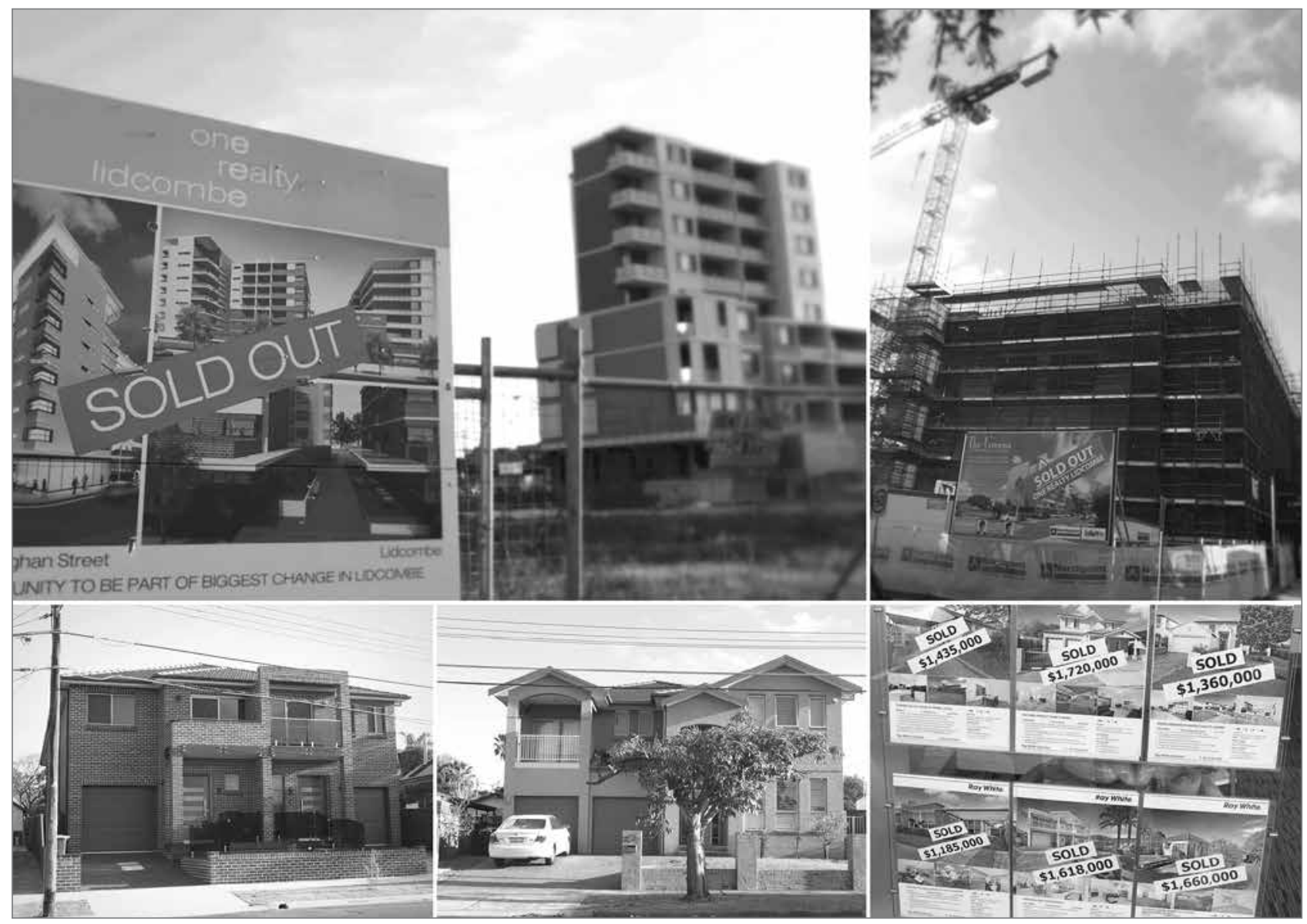

Slika 4: Gradnja nepremičnin v Lidcombu (foto: Hae Seong Jang)

Preglednica 2: Demografski in migracijski trend v Lidcombu v obdobju 2001-2011

\begin{tabular}{llll}
\hline leto & 2001 & 2006 & 2011 \\
\hline število prebivalstva & 13.454 & 14.148 & 16.403 \\
\hline ženske (\%) & 49,5 & 49,7 & 49,1 \\
\hline
\end{tabular}

Vir: Auburn City Council (2015b)

preprosto želelo živeti drugje. Na upad belopoltega prebivalstva v Lidcombu je tako vplival preplet različnih okoliščin in ne samo en odločilni dejavnik. Kot opozarja Burnley (2006), je velika koncentracija bogatih belskih sosesk v Sydneyju vedno zagotavljala močno podporo stališču, da poselitvene vzorce $\mathrm{v}$ mestu določata rasa in družbeni razred.

Iz preglednice 1 je prav tako razvidno, da v Lidcombu narašča delež nekaterih narodnosti, čeprav ima še vedno zelo raznoliko prebivalstveno strukturo. Najbolj narašča število korejskega prebivalstva. Glavni vzrok za to je, da so se cene nepremičnin v sosednji soseski Strathfield, v kateri prevladujejo Korejci, močno povišale. Lidcombe je tako ponudil zasilni izhod z vse bolj vročega nepremičninskega trga v Strathfieldu. Vse večji korejski vpliv v Lidcombu seveda v sosesko privlači še druge Korejce. Lidcombe ima tako narodnostno zelo pestro prebivalstvo in družbeno kulturo, pri čemer na tem območju sobivajo različne cerkve (slika 5). Raznovrstnost pride najbolj do izraza v spominskem parku Lidcombe Remembrance Park (glej sliko 6), kjer se zbirajo ljudje najrazličnejših narodnosti in se udeležujejo družabnih dejavnosti, se sproščajo ali pa izvajajo različne vrste lahke vadbe. Vzdušje najbolje povzame priljubljena pesem javne šole v Lidcombu:

\footnotetext{
Prihajamo iz šole v Lidcombu (plosk, plosk, plosk!) ... učenje v sožitju nam gre najbolje od rok! Naši učenci prihajajo iz številnih različnih dežel. Želimo ostati združeni na avstralski zemlji. Spoštujemo drug drugega in vsakogar, ki ga srečamo. Učenje v sožitju izpopolnjuje naše življenje.
}

Glede na to, da lahko otroci v Avstraliji obiskujejo samo javne šole na območju svoje upravne enote, besedilo te pesmi dopolnjuje statistične podatke o raznovrstnosti območja. $\mathrm{V}$ nasprotju z redko poseljenostjo $\mathrm{v}$ preteklosti danes Lidcombe kipi od človeške dejavnosti, njegovo prebivalstvo pa se stalno povečuje (glej preglednico 2).

Podatki ne vključujejo precejšnjega števila turistov, ki prihajajo $\mathrm{v}$ Lidcombe. Na podlagi pripovedovanja domačinov in sistematičnih urbanističnih raziskav (Stilwell, 1998) na rast prebivalstva v Sydneyju in njegovem predmestju najbolj vpliva prise- 


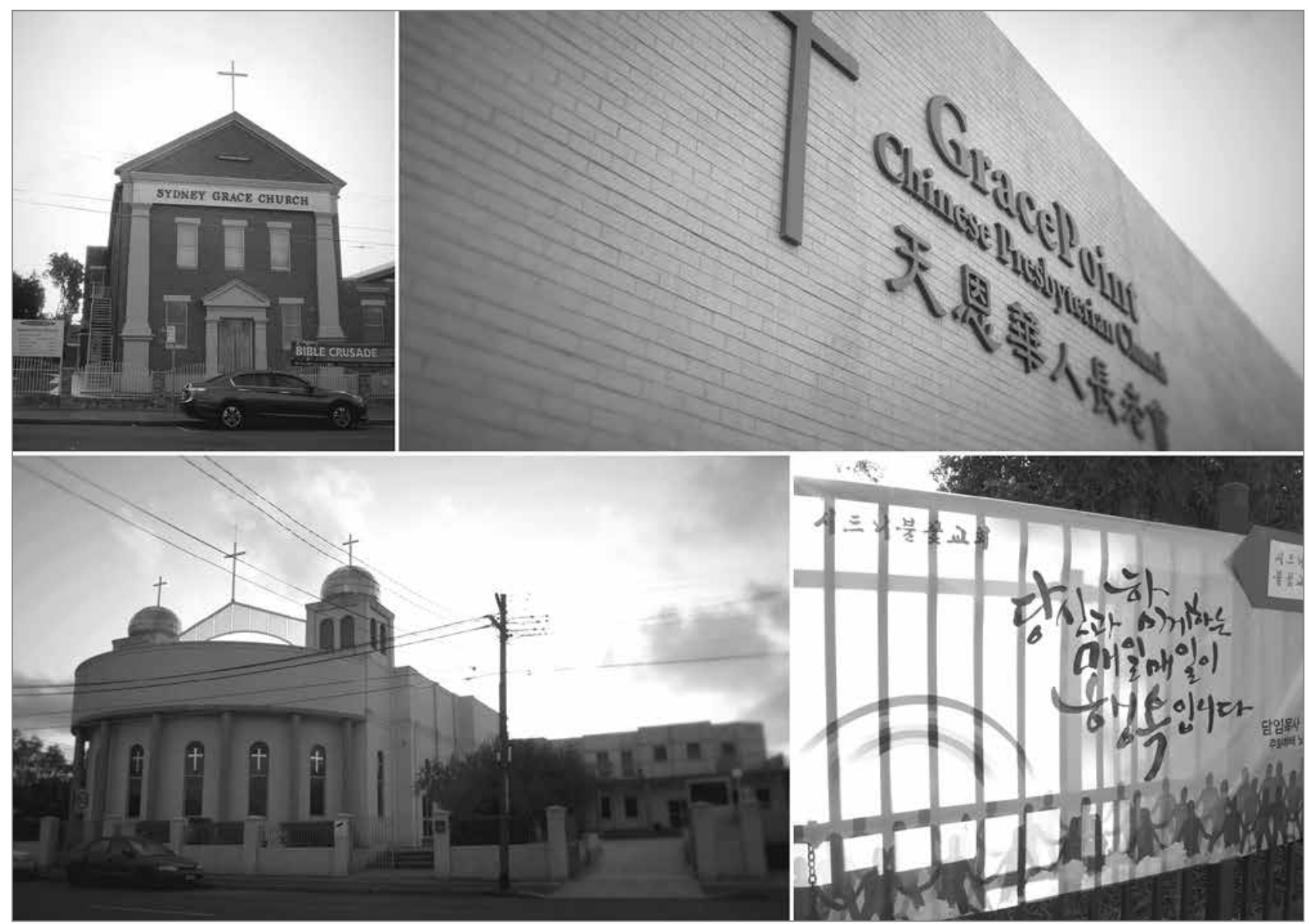

Slika 5: Različne cerkve v Lidcombu (foto: Hae Seong Jang)
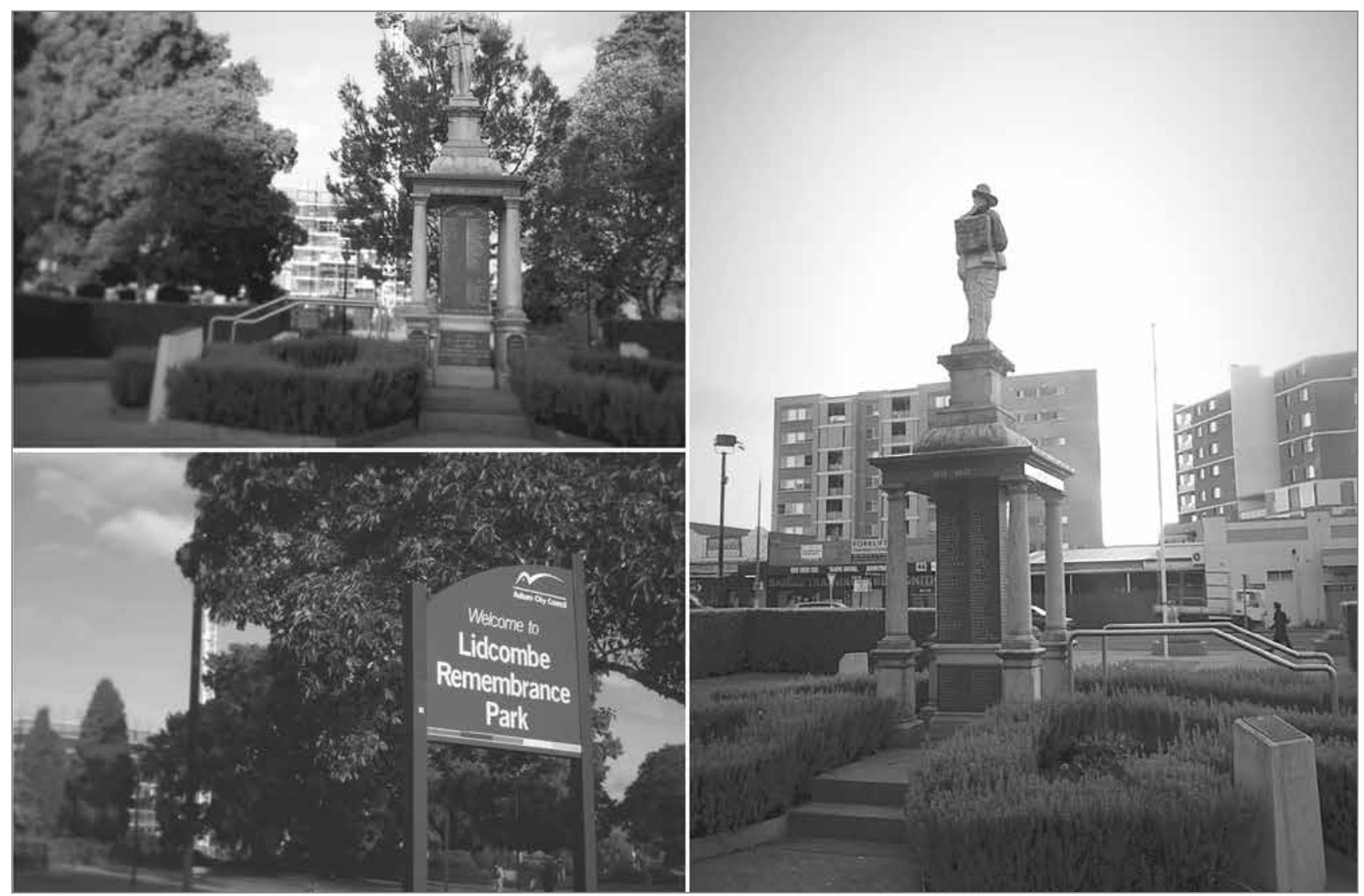

Slika 6: Spominski park v Lidcombu (foto: Hae Seong Jang) 


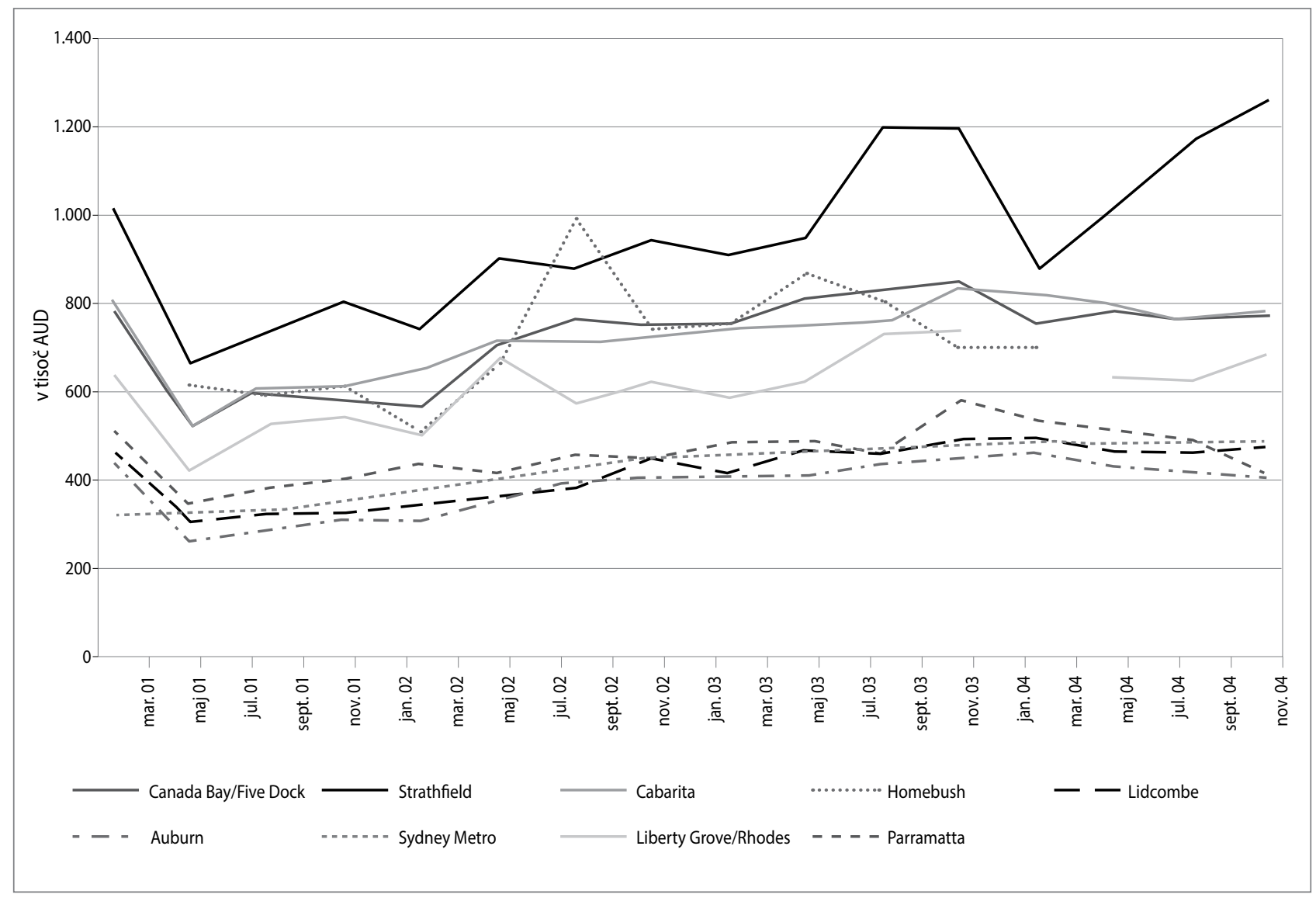

Slika 7: Povprečne prodajne cene nepremičnin v okoliških predmestjih Sydneyja v obdobju 2001-2004 (vir: Randolph idr., 2005)

ljevanje; število in delež prvotnih belih prebivalcev Lidcomba se tako znižujeta. Po navedbah nekaterih migrantov, s katerimi smo govorili, so pogost razlog za povečevanje števila priseljencev v Lidcombu razmeroma poceni stanovanja in lahek dostop do drugih delov Sydneyja zaradi železniške postaje. Večanje števila pripadnikov posameznih prebivalstvenih skupin spodbudi novo priseljevanje, saj lokacija ljudi privlači zaradi najrazličnejših razlogov, vključno z mikavnimi informacijami, lokalno skupnostjo in drugimi oblikami družbene podpore. Nekateri so se v Lidcombe priselili tudi zaradi višjih cen nepremičnin $\mathrm{v}$ drugih predelih mesta, še zlasti v sosednjem Strathfieldu (glej sliko 1; Han in Han, 2010). Še vedno pa se največ ljudi tja priseli iz drugih držav. Stanovanja v Lidcombu so v primerjavi z drugimi predmestji razmeroma poceni (glej sliko 7).

Poleg tega nudi lahek dostop do poslovnega središča mesta in drugih območij, v katerih migranti delajo, nakupujejo in se družijo. Tretjič, gre za migrantsko sosesko. Ta razlog se morda zdi samoumeven, toda migranti običajno gravitirajo $\mathrm{k}$ območjem, ki so znana po tem, da nudijo družbeno, versko in gospodarsko podporo, kar je v nasprotju z neoklasičnimi ekonomskimi teorijami, po katerih naj bi bila migracija racionalna zadeva posameznika (Molho, 2013). Te razloge so običajno navajali nepremičninski agenti, upravniki trgovin ter železniški in poštni delavci. Pastor neke korejske cerkve, ki jo obiskujejo večinoma Korejci, je 12. januarja 2014 celo pridigal o tej temi, pri čemer je potrdil tri zgoraj opisane razloge in dodal še četrtega: bog je pripeljal migrante v Lidcombe, da bi ga preoblikovali.

Dejavniki, ki so vplivali na to, da so se ljudje priselili v Lidcombe, se razlikujejo glede na izvorno državo. Na prebivalce več kot 30 različnih narodnosti, ki danes živijo v Lidcombu, so vplivali različni, včasih pa tudi podobni dejavniki (glej na primer Han in Han, 2010, za korejske priseljence v Sydneyju in Moustafine, 2011, za ruske priseljence). Če vzamemo za primer Korejo, je večje izseljevanje omogočila ukinitev prepovedi preseljevanja konec 90. let 20. stoletja.

Običajno so se migranti na to območje priselili skupaj s svojimi družinami, čeprav je prišlo tudi veliko samskih ljudi. Po podatkih o velikosti lokalnih gospodinjstev (Auburn City Council, 2013b) je trenutno samo $15 \%$ gospodinjstev enočlanskih. Dvočlanskih gospodinjstev je $26 \%$, tričlanskih $2 \%$, štiričlanskih $21 \%$, petčlanskih $9 \%$ in šestčlanskih ali več $7 \%$. Ti podatki grobo veljajo tudi za Lidcombe. Tovrstno skupinsko priseljevanje nasprotuje razlagam, ki temeljijo na posamezniku, ter njihovim dominantam in učinkom domin ali različicam 
Preglednica 3: Zaposlitvena statistika Lidcomba (južni del oziroma soseska Rookwood) v obdobju 2001-2011

\begin{tabular}{llll}
\hline zaposlitveni status & 2001 & 2006 & 2011 \\
\hline zaposleni & $2.288(90,5 \%)$ & $2.326(91,9 \%)$ & $3.421(90,4 \%)$ \\
\hline zaposleni s polnim delovnim časom & 1.549 & 1.619 & 2.175 \\
\hline zaposleni s kraǰ̌im delovnim časom & 615 & 613 & 1.084 \\
\hline število opravljenih delovnih ur ni navedeno & 124 & 94 & 162 \\
\hline brezposelni & 239 & 204 & 361 \\
\hline iskalci zaposlitve s polnim delovnim časom & 151 & 139 & 186 \\
\hline skupaj delovna sila & 2.527 & 2.530 & 3.783 \\
\hline
\end{tabular}

Vir: Auburn City Council (2015c)

v neoklasični ekonomiji (Collins, 2013). Dejstvo, da je samo ena zaposlitvena agencija, Max Employment, registrirala 1.400 iskalcev zaposlitve (Auburn Review, 2014), kaže na to, da migranti ne čakajo le na državno podporo. Njihov prispevek k lokalnemu, občinskemu in mestnemu gospodarskemu razvoju je precejšen in se ne ujema s trditvami, da samo obremenjujejo avstralsko gospodarstvo.

\section{Lokalno, občinsko in mestno gospodarstvo}

Stopnja brezposelnosti v celotni upravni enoti Auburn znaša 5,6 \% (Auburn Review, 2014) in je veliko nižja od državnega povprečja, ki znaša 6,0/6,1 \%. Pomembno pa je, da si pobliže ogledamo naselje Lidcombe. Če se osredotočimo na njegov južni del, ki je bil vedno veliko manj razvit in zaželen kot severni del, lahko vidimo, da je večina njegovih prebivalcev zaposlena s polnim ali krajšim delovnim časom in dela v Lidcombu ali zunaj njega (preglednica 3). V preglednici 3 so prikazani statistični podatki o zaposlitvenem statusu prebivalstva.

Leta 2011 je 63 \% prebivalcev Rockwooda in Lidcomba na splošno spadalo v starostno skupino od 20 do 59 let, se pravi med delovno sposobno prebivalstvo. Demografski podatki so za obe območji zelo podobni in kažejo, da migranti pretirano ne obremenjujejo javne blagajne v smislu javnih izdatkov za upokojence in starejše migrante. Prebivalci opravljajo najrazličnejša dela, in fizično delo (stereotipno delo migrantov) je samo eno od teh. Delajo kot strokovnjaki in menedžerji, tehniki in obrtniki, delavci v proizvodnji, pisarniški delavci in prodajalci. Deleži posameznih poklicev so predstavljeni v preglednici 4.

Kako živahno je lokalno gospodarstvo, pa ne moremo ugotoviti samo na podlagi teh podatkov. Vsi zaposleni namreč ne delajo v Lidcombu; to značilnost sta predmestju sistematično določila mestna uprava in značaj njegove skupnosti (Auburn City Council, 2013b). Več podatkov lahko dobimo, če pogledamo obsežen tok ljudi, ki se med prometno konico na železniški postaji Lidcombe vkrca na vlak in zapusti sosesko. Podobno vsakodnevni nenadni pritok ljudi med 6.in 7. uro zjutraj z
Preglednica 4: Poklicna struktura v Lidcombu (v deležih)*

\begin{tabular}{lll}
\hline poklic & 2006 & 2011 \\
\hline menedžerji & 8,4 & 8,2 \\
\hline strokovnjaki & 17,8 & 23,1 \\
\hline tehniki in obrtniki & 14,2 & 14,4 \\
\hline $\begin{array}{l}\text { skupnostni delavci in zaposleni v } \\
\text { storitvenem sektorju }\end{array}$ & 7,5 & 8,3 \\
\hline pisarniški delavci & 15,8 & 14,5 \\
\hline prodajalci & 9,2 & 8,4 \\
\hline upravljavci težkih strojev & 9,3 & 6,7 \\
\hline fizični delavci & 14,7 & 12,4 \\
\hline pomanjkljivi podatki & 3,3 & 3,8 \\
\hline
\end{tabular}

Opomba: * Podatki se nanašajo samo na južni del Lidcomba.

Vir: Auburn City Council (2015d)

območij zunaj Lidcomba potrjuje, da v soseski ne delajo samo tisti, ki tam živijo. Posledica gibanja v Lidcombe in iz njega je to, da izdatki nekaterih migrantov (na primer za nakupovanje in malico med službo) vplivajo na lokalna gospodarstva zunaj Lidcomba, vključno s tistim v širši občini Auburn.

Podatki o kvantitativnem prispevku Lidcomba niso na voljo, saj avstralski statistični urad, pri katerem podatke dobiva tudi mestni svet, očitno ne ponuja tovrstnih podrobnejših informacij. S kvalitativnega vidika pa vemo, da se prebivalci Lidcomba ukvarjajo z najrazličnejšimi dejavnostmi, pri čemer najbolj izstopa prodaja, ki najbolj dejavno zadovoljuje potrebe lokalnega prebivalstva in ljudi, ki prihajajo od drugod. S tem izdatki migrantov bolj neposredno vplivajo na lokalno gospodarstvo. Trgovsko oziroma poslovno središč mesta je ulica Joseph Street, na kateri lahko najdemo trgovine z živili, pekarno, frizerske salone, restavracije, bare in lekarno. Poleg tega so tam poslovni subjekti, kot so zdravstvena ambulanta, davčna agencija, pravne pisarne in gostinski lokali. Na tej ulici je tudi restavracija $s$ hitro hrano McDonalds. Na ulici Victoria Street East najdemo manjšo industrijsko cono s skromnim poslovnim centrom in nekaj manjšimi obrati, kot je selitveno podjetje. $V$ severnem delu Lidcomba je še ena dolga in živahna poslovna ulica, John Street, na kateri najdemo prastaro pivovarno Tooheys, hotele in bare. 

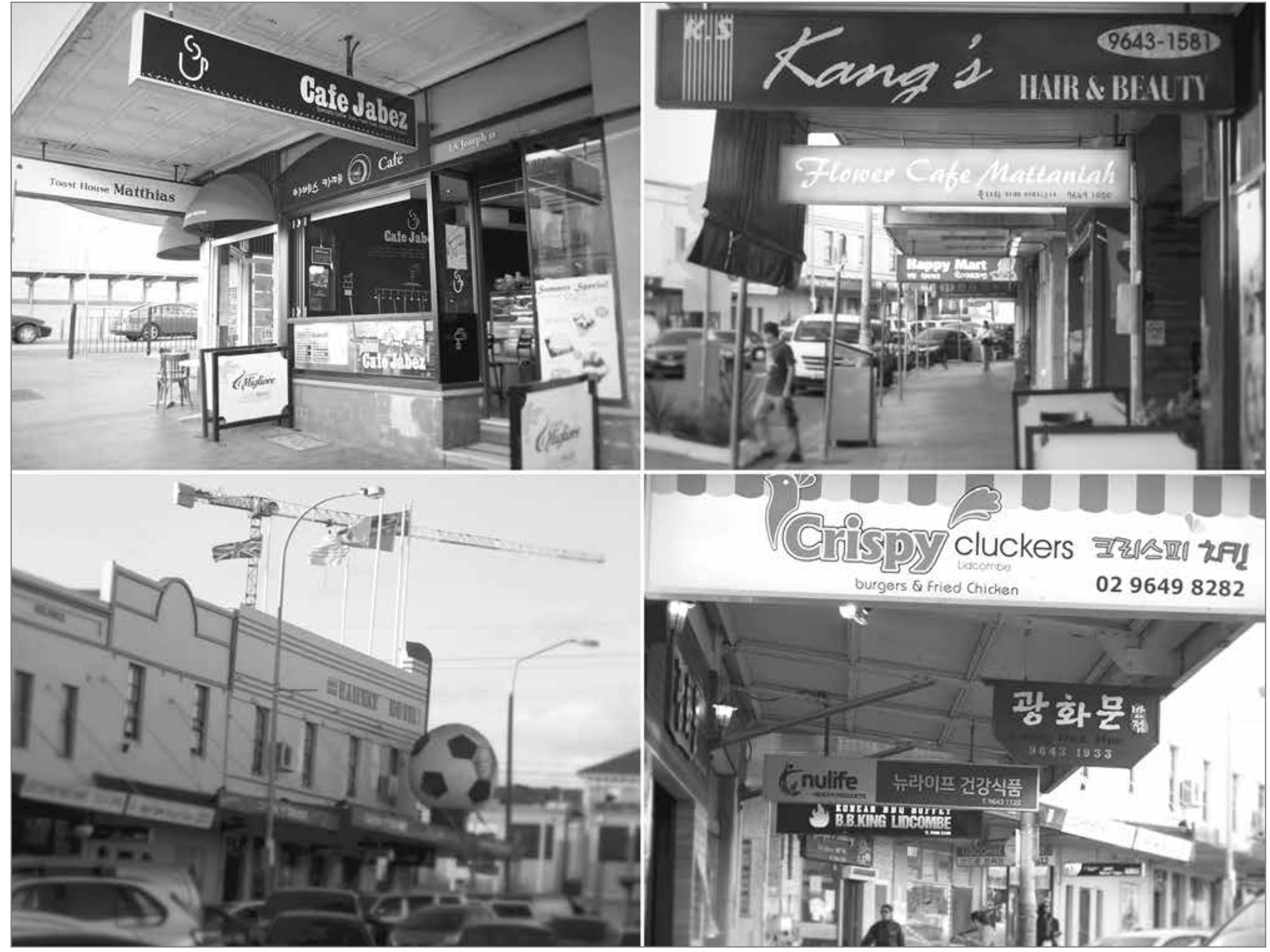

Slika 8: Večje trgovsko območje v Lidcombu (foto: Hae Seong Jang)

Preglednica 5: Kvartili dohodkov gospodinjstev v Lidcombu v obdobju 2001-2011

\begin{tabular}{|c|c|c|c|c|c|c|}
\hline Lidcombe & 2001 & srednji razred & 2006 & srednji razred & 2011 & srednji razred \\
\hline kvartilna skupina & $\%$ & & $\%$ & & $\%$ & \\
\hline najnižja & 23,0 & \multirow{4}{*}{54,4} & 25,2 & \multirow{4}{*}{53,8} & 23,2 & \multirow{4}{*}{54} \\
\hline srednje nizka & 26,9 & & 26,9 & & 26,9 & \\
\hline srednje visoka & 27,5 & & 26,9 & & 27,1 & \\
\hline najvišja & 22,5 & & 21 & & 22,9 & \\
\hline
\end{tabular}

Vir: povzeto po podatkih mestnega sveta v Auburnu (ang. Auburn City Council, 2015e)

Preglednica 6: Ključ za razlago kvartilov dohodkov gospodinjstev v obdobju 2001-2011

\begin{tabular}{llll}
\hline višina dohodkov (v AUD) & 2001 & 2006 & 2011 \\
\hline najnižja skupina & $0-418$ & $0-530$ & $0-614$ \\
\hline srednje nizka skupina & $419-828$ & $531-1.034$ & $615-1.233$ \\
\hline srednje visoka skupina & $829-1.462$ & $1.035-1.788$ & $1.234-2.272$ \\
\hline najvǐ̌ja skupina & več kot 1.463 & več kot 1.789 & več kot 2.273 \\
\hline
\end{tabular}

Vir: Auburn City Council (2015f) 
Lokalno gospodarstvo je v konjunkturi, vsaj glede na visoko stopnjo novih poslovnih dejavnosti. $\mathrm{V}$ zadnjih treh mesecih so se odprle še tri nove korejske restavracije. Ta trend je očiten zlasti na ulici Joseph Street, vendar tudi drugod. Poleg tega se v soseski odpira vse več nepremičninskih agencij. Samo na trgovskem območju na ulici Joseph Street so se v zadnjem letu odprle kar tri. Pri eni gre pravzaprav za »razširitev « prejšnje draguljarne in trgovine z živili, drugi dve pa sta bili ustanovljeni popolnoma na novo. Nimamo natančnih podatkov o njihovi donosnosti, saj te informacije niso na voljo. Kljub temu pa lahko ugotovimo, da je Lidcombe zdaj soseska, $\mathrm{v}$ kateri prevladujejo prebivalci srednjega razreda, in nič več delavsko predmestje, kot je to veljalo v preteklosti; to je razvidno tudi iz preglednice 5 .

Na podlagi pogovorov, ki smo jih v zadnjih dveh letih opravili z dolgoletnimi prebivalci te soseske, smo ugotovili, da veliko delovnega prebivalstva živi v Lidcombu, vendar pa ne vsi. Ključno pri vsem tem je dejstvo, da so tudi območja, najbližja pokopališcu, zdaj gospodarsko precej živahna. Pogrebna dejavnost je seveda še naprej dejavna. Na območju deluje podjetje, ki izdeluje nagrobnike in napise zanje in zaposluje lokalne kamnoseke. Ob podjetju, prikazanem na sliki 9, deluje na tem območju še eno, ki ga upravlja sklad, ki je upravitelj pokopališča, dejavno pa je vsaj še eno, ki je v zasebni lasti.

Pogrebni zavod Guardian Funeral Home poleg tega po naročilu načrtuje in pripravlja pogrebne slovesnosti. Podjetja, ki se ukvarjajo $s$ to dejavnostjo, aktivno oglašujejo svoje storitve, med drugim tudi v lokalnem časopisu Auburn Review, o dejavnosti nekaterih podjetij pa smo se prepričali tudi z obiskom njihovih poslovalnic. Kljub temu pa je lokalno gospodarstvo zdaj veliko bolj razvejano kot včasih.

Prihodkovni razredi so se z leti spremenili, zato je podatke v preglednici 6 treba brati skupaj s tistimi na sliki 7. Če jih beremo skupaj, ugotovimo, da v naselju vlada precejšnje blagostanje in da družbeno pomanjkanje močno upada, dohodki pa so enakomerno porazdeljeni. Migranti pošiljajo denar in darila svojim sorodnikom $\mathrm{v}$ domovini, $\mathrm{v}$ katero tudi vlagajo. Zanimivo bi bilo preučiti, ali obstajajo razlike med tem procesom in tem, kako Afričani v Sydneyju pošiljajo denar v Afriko (Obeng-Odoom, 2010).

\section{Sklep}

$\mathrm{Na}$ tem mestu se splača ponoviti vprašanje, zastavljeno na začetku članka: Kako migranti oblikujejo lokalne prostore in prispevajo k gospodarstvu in družbi države gostiteljice? Čeprav prevladuje mnenje, da so vplivi migrantov negativni, naša študija primera kaže, da je zamisel o »migracijskem vplivu« ali

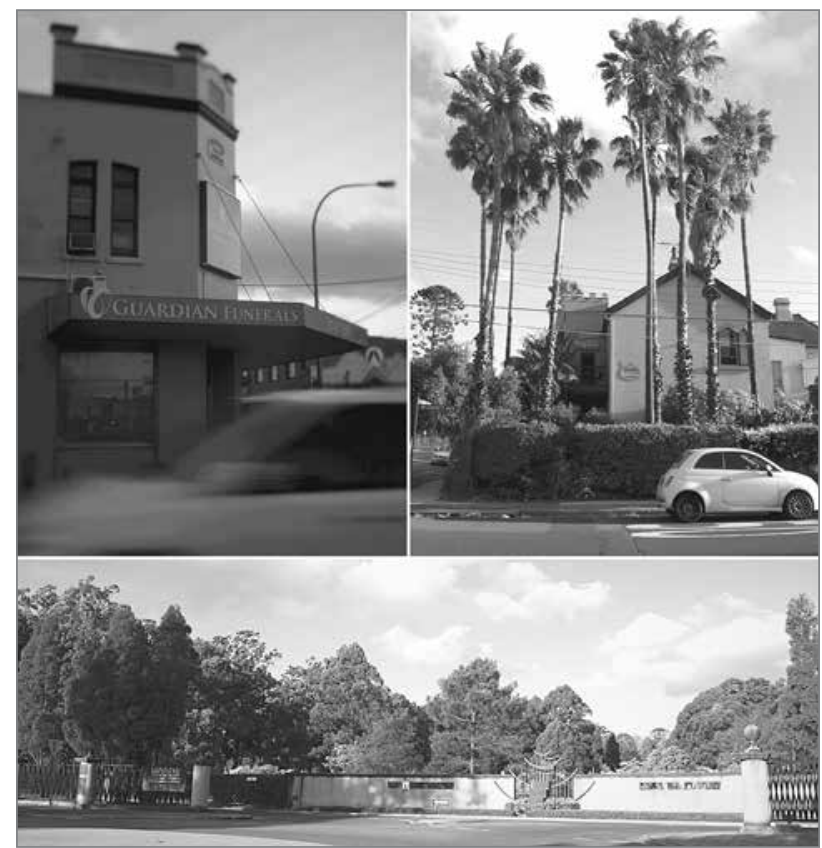

Slika 9: Pogrebna dejavnost (foto: Hae Seong Jang)

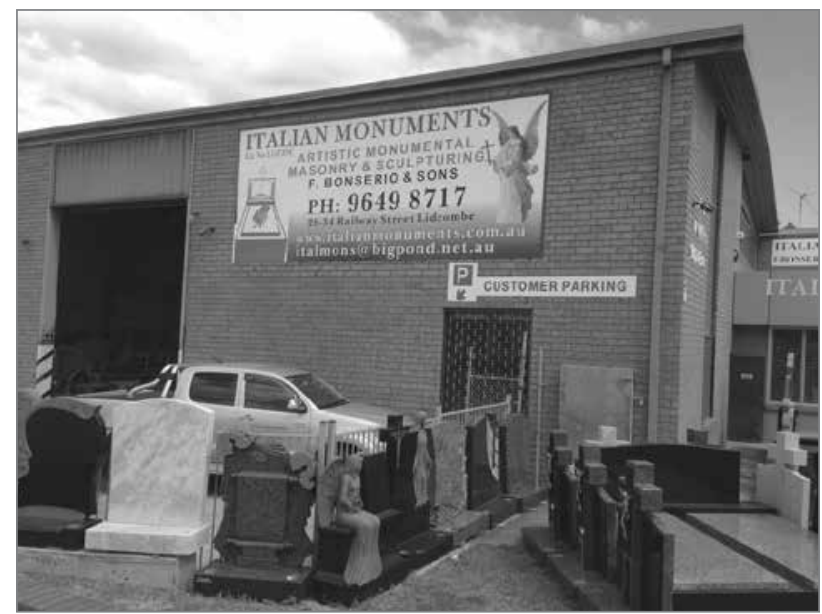

Slika 10: Podjetje v Lidcombu, ki izdeluje nagrobnike in spomenike (foto: Franklin Obeng-Odoom)

»vplivih migracij« nekoliko preveč poenostavljena. Pri problematiki migracij gre za empirično vprašanje. Lidcombe je ena večjih migrantskih sosesk v Avstraliji, ki jo ljudje močno povezujejo s smrtjo in mrtvimi, hkrati pa je v njej močno razvita gospodarska dejavnosti. Južni del Lidcomba, ki je bil prej znan predvsem kot domovanje mrtvih, je na novo oživel s prihodom migrantov, ki so dejavni v lokalnem gospodarstvu in zunaj njega, hkrati pa tudi njegov severni del ostaja še naprej živahen in dobro poseljen. Dnevne življenjske potrebe migrantov so na državo gostiteljico pozitivno vplivale, saj je tako razširila svoje gospodarske dejavnosti prek različnih kanalov, kot sta gradbeništvo in bančništvo, ter povečala družbeno in moralno raznovrstnost. Hkrati se zdi, da migranti od avstralske javnosti ne zahtevajo nešteto stvari ali storitev, ki si jih ne bi zaslužili 
ali potrebovali. Kot aktivni zaposleni migranti prispevajo $\mathrm{k}$ splošni avstralski blaginji in bodo tako upravičeni do svojega deleža, še zlasti, ker ni dokazov o porabi javnih sredstev za vzdrževanje miru in varnosti, saj se je stopnja kriminala v zadnjih letih močno znižala (Auburn City Council, 2013a). Migranti so prinesli novo življenje v Avstralijo, hkrati pa izboljšujejo tudi življenje svojih sorodnikov v domovini. Pošiljajo jim denar in jih obiskujejo, kar pomaga izboljšati družbene razmere $\mathrm{v}$ teh tujih državah, prav tako kot v primeru Lidcomba tuja delovna sila pomaga državi gostiteljici preoblikovati mrtvo mesto. Pogrebna dejavnost seveda ostaja, vendar je lokalno gospodarstvo v Lidcombu danes veliko bolj razvejano, in vse kaže, da se bo njegov družbenogospodarski napredek v prihodnosti še nadaljeval.

Opisane ugotovitve pomembno prispevajo k obstoječi literaturi o migrantih, $v$ kateri se predvideva, da so ti del diaspore in da zaradi svoje »navezanosti na domovino « ne vlagajo v države gostiteljice (Min in Park, 2014). V primeru Lidcomba se navezanost na »dom « izraža v »domači kulturi«, ki so jo migranti prinesli s seboj v Avstralijo (na primer pogosto jedo zunaj, kar za to območje prej ni bilo značilno), hkrati pa so preoblikovali staro in izumirajoče naselje. $V$ nasprotju s samo eno enklavo v mestu, kot to kažejo druge raziskave (Kim, 2014), ali samo eno regionalno skupino migrantov, ki vlaga v nepremičninski trg, kot je to pokazala predhodna študija Franklina Obeng-Odooma (2012b) o afriških migrantih v Sydneyju, v tej soseski živijo ter jo preoblikujejo migranti različnih ras, narodnosti in veroizpovedi. $\mathrm{V}$ tem pogledu raziskava prispeva $\mathrm{k}$ literaturi o migrantski preobrazbi mest, ki se je osredotočala na begunce in posamične narodnosti ali etnične enklave (na primer Stilwell, 2003). Belopolti Avstralci so se izselili, vendar še zdaleč niso bili »izrinjeni « niti prisiljeni v to, da se preselijo na manj primerna območja. V nasprotju z avstralskimi belci, ki so temnopolte domorodce pregnali na slabša in odročna območja (Jang, 2015), so se beli prebivalci Lidcomba preselili na »boljša območja «, pri čemer se jim je gospodarski položaj z odhodom izboljšal. V primeru Lidcomba torej ne gre samo za razselitev belega prebivalstva niti preprosto za to, da so posamezni migranti postali uspešni, kot to nakazujejo nekatere raziskave (Saunders, 2012).

S tem vprašanjem so povezani pomembni problemi, na primer vse večji stanovanjski stroški, slabšanje dostopa do najosnovnejših storitev, nezadostno mešanje prebivalstva in morebitna radioaktivnost. Te težave so za migracijo v Avstraliji nekaj običajnega, poleg tega pa lahko pomanjkanje kohezije vodi v morebitne politične posege, ki lahko spodbudijo večje mešanje prebivalstva. $Z$ razširjanjem raziskovalnih ugotovitev v lokalnem časopisu Auburn Review ter obveščanjem prek avdio-, pisnih in vidnih sredstev lahko izboljšamo ozaveščenost ljudi o tej problematiki. Raziskava, ki jo je o migrantih v ZDA izvedel Jerry Park (2013), je pokazala, da verska pripadnost pogosto ustvarja ločenost in $s$ tem poskrbi za ohranjanje narodne identitete, vendar lahko hkrati ponuja priložnost za spremembe v procesu integracije, še zlasti če se določena verska skupnost odloči spremeniti svojo organizacijo, kar lahko na primer omogoči medrasne poroke kot eno od mogočih oblik integracije. Mestni svet je prebivalcem zagotovil brezplačne ali subvencionirane tečaje angleškega jezika, ki so vključevali teme o različnih kulturah in rasah. Zlasti zaskrbljujoče so cene nepremičnin, ki se pogosto povečajo $\mathrm{z}$ višanjem ponudb, kar lahko vodi $\mathrm{v}$ prenapihnjenost cen in $\mathrm{s}$ tem $\mathrm{v}$ slabšo cenovno dostopnost nepremičnin v lokalnem gospodarstvu. Eden od načinov, na katerega lahko ustavimo to očitno neskladje med ponudbo in povpraševanjem ter $s$ tem potrebo po konkurenčnih ponudbah, je vzpostavitev programa obdavčenja zemlje po načelih ekonomske filozofije, ki jo je podpiral ameriški politični gospodarstvenik Henry George. S takim programom lahko ublažimo potrebo po špekuliranju v rastočem lokalnem gospodarstvu. Poleg tega se lahko uvedejo programi družbenih stanovanj, ki bi razširili ponudbo na stanovanjskem trgu, ne da bi pri tem podražili najemnine. Uvajanje tovrstnih stanovanjskih reform za migrante bo samo po sebi kontroverzno, vendar jih mestna uprava lahko izpelje, če se tako odloči, še zlasti zdaj, ko ima mestni svet v migrantih močno volilno zaledje. Iz istega razloga bi se lahko okrepila prizadevanja za preprečitev uresničitve načrtov, po katerih naj bi se Lidcombe spremenil v odlagališ̌ce radioaktivnih odpadkov. Natančnejša analiza narave politike sprememb in tega, kako se lahko različne interesne skupine uprejo spremembam ali kako jih je mogoče prepričati, da podprejo spremembe, pa bo morala še malo počakati.

Za zdaj bo dovolj, če poudarimo, da so migranti v avstralsko mrtvo mesto prinesli novo življenje, hkrati pa so to omogočili tudi samim sebi in svojim sorodnikom v domovini - ne da bi pri tem pretirano obremenjevali avstralsko gospodarstvo. Ker imajo vzorci priseljevanja (priseljevanje v skupinah) ter procesi sprememb in stalnosti v Lidcombu strukturno in zgodovinsko podlago in dinamiko, se zgodba te soseske ne ujema $\mathrm{z}$ domnevami o priseljevanju posameznikov, na katerih temelji veliko ekonomskih teorij. Avstralska migracijska politika (politika dodeljevanja vizumov migrantom) bi tako morala bolj ustrezati »zgodovinsko-strukturni « paradigmi migracij kot splošnejši neoklasični »ekonomiji migracij«. Migranti so glavna gonilna sila velike preobrazbe v Lidcombu in lahko nudijo močno oporo novim migrantom, pri čemer ne potrebujejo pomoči oblikovalcev politike ne drugih, katerih odgovor se kar naprej glasi »samo prek mojega trupla «.

Franklin Obeng-Odoom

University of Technology Sydney, Australia, School of Built Enviro-

nment, Avstralija

E-pošta: Franklin.Obeng-Odoom@uts.edu.au 
Hae Seong Jang

The University of Sydney (former) and currently affiliated with Yonsei University, Centre for Australian Studies, Južna Koreja

E-pošta: hjan2486@uni.sydney.edu.au

\section{Zahvala}

Zahvaljujeva se Davidu in Noli Basford, ki že dolgo živita v Lidcombu in ga izjemno dobro poznata, za vse informacije in arhivsko gradivo o tej soseski. Poleg tega se zahvaljujeva nepremičninskim agentom in drugim (železniškim delavcem, zaposlenim $v$ verskih organizacijah, lastnikom trgovin, prodajalcem in zaposlenim v knjižnici), ki so z nama delili svoja mnenja o preobrazbi Lidcomba. Posebna zahvala gre prof. Franku Stilwellu, vodilnemu avstralskemu urbanističnemu političnemu ekonomistu, za pomoč pri razlagi širšega konteksta urbanega razvoja Avstralije v začetnih fazah oblikovanja raziskave. Pri izboljšavi članka so nama bili v veliko pomoč predlogi zunanjega ocenjevalca revije Urbani izziv in podpora njenega glavnega urednika dr. Boštjana Kerblerja. Nobena od omenjenih oseb ni odgovorna za kateri koli vidik predstavljene analize, zanjo prevzemava popolno odgovornost.

\section{Opombe}

[1] Podatki so bili pridobljeni 11. januarja 2014. z uporabo iskalnika Google Scholar (uporabljene ključne besede: Frank Stilwell, Afghans).

[2] Časopisi so prav tako navajali, da so bile na območju črne vrane (ang. crows) in ne sive (ang. rooks). Kakorkoli že, ker gre $v$ obeh primerih za vrsto vrane, je ime »Rook« v redu (odlomek na strani 234, Hedges, 1992).

\section{Viri in literatura}

Abreu, A. (2012): The new economics of neoclassicals bearing gifts. Forum for Social Economics, 41(1), str. 46-67. DOI: $10.1007 / \mathrm{s} 12143-010-9077-2$

Acharya, A. K., in Codina, M. R. B. (2012): Social segregation of indigenous migrants in Mexico: An overview from Monterrey. Urbani izziv, 23(1), str. 140-149. DOI: 10.5379/urbani-izziv-en-2012-23-01-006

Adogame, A., in Lawrence, A. (2014) (ur.): Africa in Scotland, Scotland in Africa: Historical legacies and contemporary hybridities. Leiden, Brill.

Ashton, P. (2008): Suburban Sydney. Sydney Journal, 1(3), str. 36-50.

Auburn City Council (2012): Economic profile: Business counts (staff) - Auburn City. Dostopno na: http://www.economicprofile. com.au (sneto 5. 6. 2014).

Auburn City Council (2013a): Auburn Crime Prevention Plan, 2013-2016. Auburn.

Auburn City Council (2013b): Community profile. Dostopno na: http:// profile.id.com.au/auburn (sneto 12. 9. 2015)

Auburn City Council (2015a): Community profile, Auburn City: Birthplace - Auburn City. Dostopno na: http://profile.id.com.au/auburn/birthplace (sneto 8. 10. 2015).

Auburn City Council (2015b): Community profile, Auburn City: Populations, dwellings, and ethnicity - Auburn City. Dostopno na: http://profile.id.com.au/auburn/population (sneto 8. 10. 2015).
Auburn City Council (2015c): Community profile, Auburn City: Employment status - Auburn City. Dostopno na: http://profile.id.com.au/ auburn/employment-status (sneto 8. 10. 2015).

Auburn City Council (2015d): Community profile, Auburn City: Occupation of employment - Auburn City. Dostopno na: http://profile.id.com.au/ auburn/occupations (sneto 8. 10. 2015).

Auburn City Council (2015e): Community profile, Auburn City: Household income quartiles - Auburn City. Dostopno na: http://profile.id.com.au/ auburn/household-income-quartiles (sneto 8. 10. 2015).

Auburn City Council (2015f): Community profile, Auburn City: Household income quartiles - Auburn City. Dostopno na: http://profile.id.com.au (sneto 8. 10. 2015).

Auburn Review (1988): Let Lidcombe live again! Auburn Review, 20. 7. 1988 .

Auburn Review (2008): Migrant concern. Auburn Review, 29. 4. 2008.

Auburn Review (2014): Hunt on for local work. Auburn Review, 7. 10. 2014.

Broomhill, R. (2008): Australian economic booms in historical perspective. Journal of Australian Political Economy, 61(June), str. 12-29.

Burnley, I. (2006): Sydney's changing peoples: Local expressions of diversity and difference. V: Freestone, R., Randolf, B., in Butler-Bowdon, C. (ur.) Talking about Sydney: Population, community and culture in contemporary Sydney, str. 37-50. Sydney, UNSW Press Ltd and Historic Houses Trust.

Castles, S. (2008): International migration at the beginning of the twenty-first century: Global trends and issues. International Social Science Journal, 52(165), str. 269-281. DOI: 10.1111/1468-2451.00258

Collins, J. (2008): Globalisation, immigration and the second long post-war boom in Australia. Journal of Australian Political Economy, 61(June), str. 244-266.

Collins, J. (2013): Rethinking Australian immigration and immigrant settlement policy. Journal of Intercultural Studies, 34(2), str. 160-177. DOI: $10.1080 / 07256868.2013 .781981$

Collins, J., Gibson, K., Alcorso, C., Castels, S., in Tait, D. (1995): A shop full of dreams: Ethnic small business in Australia. Sydney, Pluto Press.

Čolić-Peisker, V. (2004): Australian Croatians at the beginning of the twenty-first century: A changing profile of the community and its public representation. Croatian Studies Review, 3-4(1), str. 1-26.

Davidson, K., in Gleeson, B. (2013): The urban revolution that isn't: The political economy of the 'New Urbanology'. Journal of Australian Political Economy, 72(summer), pp. 52-79.

Department of Infrastructure and Transport (2013): State of Australian Cities Report 2013. Canberra, Major Cities Unit, Government of Department of Infrastructure and Transport Canberra.

Division of Local Government, Department of Premier and Cabinet (2013): Local Council Boundaries Sydney Outer (SO). Sydney, New South Wales Government. Dostopno na: http://www.dlg.nsw.gov.au (sneto 4. 1. 2013).

Emerson, A. (2001): Historical dictionary of Sydney. Lanham, MD, Scarecrow Press, Inc.

Glaeser, E. (2012): Triumph of the city. London, Pan Books.

Gordon, L. (2008): Berala. Sydney Journal, 1(3), str. 110-112.

Gunter, A. (2014): Renting shacks: Landlords and tenants in the informal housing sector in Johannesburg South Africa. Urbani izziv, 25(supplement), str. 96-107.

DOI: 10.5379/urbani-izziv-en-2014-25-supplement-007 
Han, J. J., in Han, G. S. (2010): The Koreans in Sydney. Sydney Journal, 2(2), str. 25-35.

Handmer, J. W. (1995): Managing vulnerability in Sydney: Planning or providence, GeoJournal, 37(3), str. 355-368. DOI: 10.1007/BF00814017

Hedges, S. L. (1992): Liberty plains: A history of Auburn, NSW. Sydney, George Lewis Group.

Hugo, G. J. (2008): In and out of Australia: Rethinking Indian and Chinese skilled migration to Australia. Asian Population Studies, 3(4), str. 267-291. DOI: 10.1080/17441730802496508

Jang, H. S. (2015): Social identities of young indigenous people in contemporary Australia: Neo-colonial north, Yarrabah. New York, Springer. DOI: 10.1007/978-3-319-15569-2

Johnson, J. (2009): Croydon. Sydney Journal, 2(1), str. 92-97.

Kass, T. (2008): Lidcombe. Dictionary of Sydney. Dostopno na: http://dictionaryofsydney.org/entry/lidcombe (sneto 14. 9. 2015).

Kim, H. H.-S. (2014): Immigrant network structure and perceived social capital: A study of the Korean ethnic enclave in Uzbekistan. Development and Society, 43(2), str. 351-379.

Kotze, N. (2013): A community in trouble? The impact of gentrification on the Bo-Kaap, Cape Town. Urbani izziv, 24(2), str. 124-132. DOI: 10.5379/urbani-izziv-en-2013-24-02-004

Lalich, W. F. (2004): The development of Croatian communal places in Sydney. Croatian Studies Review, 3-4(1), str. 95-124.

Marais, L., Ntema, J., Cloete, J., in Venter, A. (2014): From informality to formality to informality: Extralegal land transfers in an upgraded informal settlement of South Africa. Urbani izziv, 24(2), str. 46-54.

DOI: 10.5379/urbani-izziv-en-2014-25-supplement-011

Markaki, Y., in Longhi, S. (2013): What determines attitudes to immigration in European countries? An analysis at the regional level. Migration Studies, 1(3), str. 311-337. DOI: 10.1093/migration/mnt015

McGrath-Champ, S., Rosewarne, S., in Rittau, Y. (2011): From one skill shortage to the next: The Australian construction industry and geographies of a global labour market. Journal of Industrial Relations, 53(4), str. 467-485. DOI: 10.1177/0022185611412897

Min, P. G. (2014): Twice-migrant Chinese and Indians in the United States: Their origins and attachment to their original homeland. Development and Society, 43(2), str. 381-401.

Mitchell, J. (2008): John Joseph Therry - His Lidcombe property. Australian Railway History, September, str. 308-310.

Molho, I. (2013): Theories of migration: A review. Scottish Journal of Political Economy, 60(5), str. 526-556. DOI: 10.1111/sjpe.12022

Monare, P. T., Kotze, N., in McKay, T. M. (2014): A second wave of gentrification: The case of Parkhurst, Johannesburg, South Africa. Urbani izziv, 25(supplement), str. S108-S121.

DOI: 10.5379/urbani-izziv-en-2014-25-supplement-008

Mourad, H. (2009): The development and land use impacts of local mosques. Diplomsko delo. Sydney, UNSW, Faculty of the Built Environment.

Moustafine, M. (2011): Russians. Sydney Journal, 3(2), str. 55-64.

Obeng-Odoom, F. (2010): Urban real estate in Ghana: A study of housing-related remittances from Australia. Housing Studies, 25(3), str. 357373. DOI:10.1080/02673031003711568

Obeng-Odoom, F. (2012a): Political economic origins of Sekondi-Takoradi, West Africa's new oil city. Urbani izziv, 23(2), str. 121-130. DOI: 10.5379/urbani-izziv-en-2012-23-02-005
Obeng-Odoom, F. (2012b): The Ghana House Trust: An innovation by migrants? Global Built Environment Review, 8(1), str. 37-44.

Obeng-Odoom, F. (2013): Review of 'Arrival city: How the largest migration in history is reshaping our world'. African Review of Economics and Finance, 5(1), str. 76-78.

Obeng-Odoom, F. (2014): Oiling the urban economy: Land, labour, capital, and the state in Sekondi-Takoradi. London, Routledge.

Opoko, A. P., Ibem, E. O. \& Adeyemi, E. A. (2015) Housing aspiration in an informal urban settlement: A case study. Urbani izziv, 26(2), pp. 117-131. DOI: 10.5379/urbani-izziv-en-2015-26-02-003

Ozkul, D., in Obeng-Odoom, F. (2013): Temporary migration in Africa: Views from the global south. African Review of Economics and Finance, $5(1)$, str. 2-8.

Park, J. Z. (2013): Ethnic insularity among 1.5 - and Second-Generation Korean-American Christians. Development and Society, 42(1), str. 113-136. DOI: 10.2139/ssrn.2736054

Pickering, J. (2001): Globalisation: A threat to Australian culture? Journal of Australian Political Economy, 48(December), str. 46-59.

Pollen, F. (1988): The book of Sydney suburbs. Auckland, Angus \& Robertson Publishers.

Portes, A., in Yiu, J. (2013): Entrepreneurship, transnationalism, and development. Migration Studies, 3(1), str. 75-95.

DOI: $10.1093 /$ migration/mns036

Randolph, B., Holloway, D., in Ruming, K. (2005): Social outcomes of residential development, Sydney Olympic Park Stage 1: Local area analysis. Sydney, UNSW, City Futures Research Centre Publication.

Riley, R., in Weale, M. (2006): Commentary: Immigration and its effects. National Institute Economic Review, 198(oktober), str. 4-9. DOI: $10.1177 / 0027950106074029$

Saunders, D. (2012): Arrival city: How the largest migration in history is reshaping our world. New York, Vintage Books.

Serra, P. (2012): Global businesses "from below": Ethnic entrepreneurs in metropolitan areas. Urbani izziv 23(supplement 2), str. S97-S106. DOI: 10.5379/urbani-izziv-en-2012-23-supplement-2-008

Stafford, T. (1991): Living in Liddy. Sydney, Ettalong Beach.

Stilwell, F. (1998): Globalization and cities: An Australian perspective. Review of Radical Political Economics, 30(4), str. 139-167. DOI: 10.1177/048661349803000407

Stilwell, F. (2003): Refugees in a region: Afghans in Young, NSW. Urban Policy and Research, 21(3), str. 235-248. DOI: $10.1080 / 0811114032000113635$

Stilwell, F. J. B. (1979): Australian urban and regional development in the late 1970s: An overview. International Journal of Urban and Regional Research, 3(1-4), str. 527-541. DOI: 10.1111/j.1468-2427.1979.tb00805.x

Šutalo, I. (2004): Croatians in Australia: Pioneers, settlers and their descendants. Kent Town SA, Wakefield Press.

Tsenkova, S. (2014): The housing policy nexus and people's responses to housing challenges in post-communist cities. Urbani izziv, 24(2), str. 90-106. DOI: 10.5379/urban-izziv-en-2014-25-02-002 